\title{
The Coronavirus Disease 2019 (COVID-19): Key Emphasis on Melatonin Safety and Therapeutic Efficacy
}

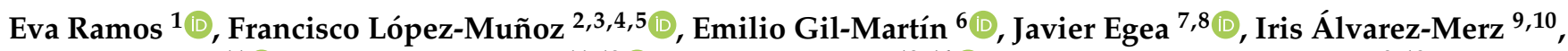 \\ Sakshi Painuli ${ }^{11}\left(\mathbb{D}\right.$, Prabhakar Semwal ${ }^{11,12} \mathbb{D}$, Natália Martins ${ }^{13,14} \mathbb{D}$, Jesús M. Hernández-Guijo ${ }^{9,10}$ \\ and Alejandro Romero ${ }^{1, *(D)}$
}

1 Department of Pharmacology and Toxicology, Faculty of Veterinary Medicine, Complutense University of Madrid, 28040 Madrid, Spain; eva.ramos@ucm.es

2 Faculty of Health Sciences, University Camilo José Cela, C/Castillo de Alarcón 49, Villanueva de la Cañada, 28692 Madrid, Spain; flopez@ucjc.edu

3 Neuropsychopharmacology Unit, Hospital 12 de Octubre Research Institute (i + 12), Avda. Córdoba, s/n, 28041 Madrid, Spain

4 Portucalense Institute of Neuropsychology and Cognitive and Behavioural Neurosciences (INPP), Portucalense University, R. Dr. António Bernardino de Almeida 541, 4200-072 Porto, Portugal

5 Thematic Network for Cooperative Health Research (RETICS), Addictive Disorders Network, Health Institute Carlos III, MICINN and FEDER, 28029 Madrid, Spain

6 Nutrition, Food \& Plant Science Group NF1, Department of Biochemistry, Genetics and Immunology, Faculty of Biology, University of Vigo, 36310 Vigo, Spain; egil@uvigo.es

check for

updates

Citation: Ramos, E.; López-Muñoz, F.; Gil-Martín, E.; Egea, J.;

Álvarez-Merz, I.; Painuli, S.; Semwal,

P.; Martins, N.; Hernández-Guijo,

J.M.; Romero, A. The Coronavirus

Disease 2019 (COVID-19): Key

Emphasis on Melatonin Safety and Therapeutic Efficacy. Antioxidants 2021, 10, 1152. https://doi.org/ 10.3390/antiox10071152

Academic Editors: Helen Galley and Juan Carlos Mayo

Received: 19 June 2021

Accepted: 14 July 2021

Published: 20 July 2021

Publisher's Note: MDPI stays neutral with regard to jurisdictional claims in published maps and institutional affiliations.

Copyright: (c) 2021 by the authors. Licensee MDPI, Basel, Switzerland. This article is an open access article distributed under the terms and conditions of the Creative Commons Attribution (CC BY) license (https:/ / creativecommons.org/licenses/by/ $4.0 /)$.
7 Health Research Institute, Hospital Universitario de la Princesa, 28006 Madrid, Spain; javier.egea@inv.uam.es

8 Molecular Neuroinflammation and Neuronal Plasticity Research Laboratory, Hospital Universitario Santa Cristina, Instituto de Investigación Sanitaria-Hospital Universitario de la Princesa, 28006 Madrid, Spain

9 Department of Pharmacology and Therapeutic, Teófilo Hernando Institute, Faculty of Medicine, Universidad Autónoma de Madrid, Av. Arzobispo Morcillo 4, 28029 Madrid, Spain;

iris.alvarez@estudiante.uam.es (I.Á.-M.); jesusmiguel.hernandez@uam.es (J.M.H.-G.)

10 Ramón y Cajal Institute for Health Research (IRYCIS), Hospital Ramón y Cajal, Carretera de Colmenar Viejo, Km. 9100, 28029 Madrid, Spain

11 Department of Biotechnology, Graphic Era University, Dehradun, Uttarakhand 248002, India; sakshipainuli@geu.ac.in (S.P.); semwal.prabhakar@geu.ac.in (P.S.)

12 Uttarakhand State Council for Science and Technology, Dehradun, Uttarakhand 248007, India

13 Faculty of Medicine, Institute for Research and Innovation in Health (i3S), University of Porto, Alameda Prof. Hernâni Monteiro, 4200-319 Porto, Portugal; ncmartins@med.up.pt

14 Institute for Research and Advanced Training in Health Sciences and Technologies, Cooperativa de Ensino Superior Politécnico e Universitário (CESPU), Rua Central de Gandra, 1317, 4585-116 Gandra, Portugal

* Correspondence: manarome@ucm.es; Tel.: +34-913-943970

Abstract: Viral infections constitute a tectonic convulsion in the normophysiology of the hosts. The current coronavirus disease 2019 (COVID-19) pandemic is not an exception, and therefore the severe acute respiratory syndrome coronavirus 2 (SARS-CoV-2) infection, like any other invading microbe, enacts a generalized immune response once the virus contacts the body. Melatonin is a systemic dealer that does not overlook any homeostasis disturbance, which consequently brings into play its cooperative triad, antioxidant, anti-inflammatory, and immune-stimulant backbone, to stop the infective cycle of SARS-CoV-2 or any other endogenous or exogenous threat. In COVID-19, the corporal propagation of SARS-CoV-2 involves an exacerbated oxidative activity and therefore the overproduction of great amounts of reactive oxygen and nitrogen species (RONS). The endorsement of melatonin as a possible protective agent against the current pandemic is indirectly supported by its widely demonstrated beneficial role in preclinical and clinical studies of other respiratory diseases. In addition, focusing the therapeutic action on strengthening the host protection responses in critical phases of the infective cycle makes it likely that multi-tasking melatonin will provide multi-protection, maintaining its efficacy against the virus variants that are already emerging and will emerge as long as SARS-CoV-2 continues to circulate among us.

Keywords: melatonin; SARS-CoV-2; safety; adjuvant therapy; mitochondria; inflammation; antioxidant; circadian rhythms; clinical trials 


\section{Introduction}

Recently, the rapid spread of new coronaviruses throughout the world has had a great impact on worldwide societal and economic development, besides it is being considered the most crucial global health disaster of the century [1]. The ongoing pandemic of coronavirus disease 2019 (COVID-19) caused by the severe acute respiratory syndrome coronavirus 2 (SARC-CoV-2) has a plethora of presentations, drifting from asymptomatic to a severe state of the disease, with a wide variety of symptoms [2]. Globally, considering its high mortality and unexpected rapid spread, several groups of academia, industry, and the government sector are working together to develop an effective and safe treatment against COVID-19. Besides pharmacological therapy, few scientific groups are working on nonpharmacological molecules that may reduce the risk of getting infected with COVID-19.

Melatonin plays an important role in the regulation of different physiological functions including free radical detoxification and immune system enhancing, besides exerting direct anti-inflammatory, anti-cancer, neuroprotective, cardiovascular, and anti-diabetic effects [3-8]. At a physiological level, the synthesis of melatonin takes place during darkness in a light-dark cycle; therefore, it is described as the indoleamine of darkness and/or a chronobiotic molecule [9].

In the last months, moved by impotence in the face of the horror caused by COVID-19, numerous researchers have emphasized the therapeutic potential of melatonin [10-12]. The pineal indoleamine is one of the molecules about which probably more pages have been written on its evolutionary origin, functionality, and applicability in clinical settings. As a result, its functional biology is one of the best-known, and we now realize that it goes far beyond the traditional role in controlling the circadian and seasonal cycles. On the contrary, melatonin is currently considered a universal cell protector with signaling actions in a myriad of biochemical processes essential for cell and tissue homeostasis $[13,14]$. In this sense, among the plethora of mediations that melatonin carries out, the regulation of immunoinflammatory responses and the protection against oxidative damage are the focus of interest. These two properties are the main pillars on which the commitment of many scientists to the administration of melatonin for the combat of SARS-CoV-2's pathogenicity [15] and other virus types [16-18].

The vast research around SARS-CoV-2 developed last year signals a double indirect contribution of melatonin-mediated responses to the natural defense against COVID-19 morbimortality [19]. First, the viral "superimmunity" of bats [20] and the presumed primary reservoir of SARS-CoV-2 and other corona/filoviruses, along with the decline of melatonin in the elderly [21], allow us to hypothesize that (i) high endogenous melatonin provides greater antiviral resistance to bats than to humans and (ii) higher melatonin in childhood protects children from COVID-19 better than adults [22,23]. Consistent with this assumption, it makes sense that in silico drug repurposing projections from human/SARSCoV-2 global protein-protein interactome network and retrospective and observational analyses of COVID-19 and non-COVID-19 cohorts have revealed the therapeutic as well as the antiviral prophylactic mechanistically based utility of melatonin, alone or in combination with other compounds [24,25]. Additionally, it is equally conceivable that from strictly theoretical considerations based on the electronic structure of the molecule, the functionality of melatonin has been predicted, and docking simulations have suggested the potential efficacy of the indoleamine in the treatment of COVID-19 [26], presuming its role as SARS-CoV-2 protease inhibitor [27]. Furthermore, to address potential treatments, network-based prediction and a propensity score-matching observational study of more than 18,000 COVID-19 patients were combined and showed melatonin reducing the capacity to drop COVID-19 risk by $64 \%$ [25]. On the empirical side, the observational study of a large COVID-19 cohort showed that patients taking melatonin had a reduced risk of SARSCoV-2 infection, even compared with those treated with potent angiotensin-converting enzyme inhibitors or angiotensin II receptor blockers, among others [25]. Likewise, individuals on melatonin treatment, along with other pharmacological, genre, ethnicity, and age features, have been positively discriminated as reduced-risk for COVID-19 by a 
logistic regression algorithm over more than 11,000 people [28]. Moreover, the translational applicability of this molecule stands out over other therapy drug candidates to effectively and safely curtail the COVID-19 pandemic $[10,25,29]$, as well as to enhance the immune response to vaccination [16,30-32].

Secondly, another plane in favor of melatonin in managing the immunopathology burden of COVID-19 is directly envisaged from the predictable efficacy of its wide-ranging capacities. This is the case of aberrant "cytokine storm syndromes", critical events of massive production and release of pro-inflammatory mediators orchestrated by the abnormal response of the immune-inflammatory system and which determine the fatal course of COVID-19 patients [33]. The prolonged recruitment in the lower respiratory tract of the host innate inflammatory lineages (macrophages, neutrophils, and mast cells) promote epithelial/endothelial apoptosis, diffuse alveolar epithelium damage, and tissue remodeling, leading to acute respiratory distress syndrome (ARDS), hypercoagulability, and clotting microthrombi, as well as switching to aerobic glycolysis responsible for the lactate dehydrogenase elevation and lactic acidosis frequently diagnosed in COVID-19 patients [34,35]. Later, hyper-inflammation by SARS-CoV-2 eventually leads to severe failure of the lungs, heart, and other peripheral organs, septic shock, and the irreversible perturbation of those whole biosystems that configure COVID-19 pathogenesis and determines the prognosis of patients, often ending in death [36,37]. However, at the same time, this immune-inflammatory status provides clues for the design of therapeutic approaches capable of adequately modulating the immune response. In this regard, melatonin can modulate innate and adaptive immunities, avoiding overreaction and the pathological escalation of the cytokine storm. In other words, the indoleamine helps to enhance host tolerance and overcome the viral cycle, preventing the systemic damage of tissues and organs $[18,38]$. From the biological perspective, melatonin raises barriers against virus invasion and replication, so the infective strategy usually involves torpedoing its synthesis and signaling to hinder the crucial antioxidant, metabolic, and immune-modulatory actions played by the indoleamine in the defense of cellular homeostasis [19,39,40]. In accordance with the above, as melatonin is produced endogenously and is also present in our diet, many researchers propose to supplement natural intakes with the indoleamine to emulate in COVID-19 patients the benefits observed in entities with phenotypic similarities. The high tolerability of melatonin, even at high doses [41,42], enhances the plausibility of efficient and safe melatonin-based COVID-19 treatments.

The alliance of dysfunctional innate/adaptive immunities with inflammation explains the enhanced susceptibility and devastating progress of COVID-19 in the elderly and patients affected by chronic primary diseases $[43,44]$. Only the increased risk of the high SARS-CoV-2 infectivity rate with age represents an immense public health challenge, since a potential population of more than 1.7 billion people worldwide of all countries and ethnicities may end up suffering from severe COVID-19 [45]. In anticipation of future scenarios of equal or greater complexity than COVID-19, the reinforcement of the host defense mechanisms provided by melatonin has the additional interest that a similar base treatment could be effective for other upcoming viral or microbial nosological entities associated with exacerbated immunoinflammation [18]. In sum, it is an ancient molecule at the forefront of future therapeutics. This is the promise that the urgent program of systematic investigation, which we want to claim herein, may put in our hands.

\section{SARS-CoV-2: From Biological Features to Pathophysiology}

Coronaviruses are the largest group of viruses responsible for respiratory, gastrointestinal, and central nervous system (CNS) infections [46]. They can be divided into four genera, including alpha $(\alpha)$, beta $(\beta)$, gamma $(\gamma)$, and delta $(\delta)$. Among these, alpha and beta only infect mammals, whereas gamma and delta primarily infect birds with few deviations [47]. Based on its phylogenic analysis and genomic construction, the SARS-CoV-2 has its place in the beta group (Hu et al., 2020). Taxonomically, SARS-CoV-2 belongs to the family Coronaviridae, order Nidovirales and genus Coronavirus. Morphologically, they 
are large, enveloped, positive-sense, single-stranded, RNA viruses, with a genome size of $\sim 30,000$ bases [48], typically round or multi-shaped with a $65-125 \mathrm{~nm}$ diameter consisting of a triple Spike glycoprotein. With high throughput sequencing, research groups have done the sequencing of SARS-CoV-2 and declared that the RNA includes 14 putative open reading frames (ORFs) encoding 27 proteins $[49,50]$. Moreover, it was confirmed that the sequence of SARS-CoV-2 has similarities with SARS-CoV (40\%) and MERS-CoV (40\%) [51]. Coronavirus genomes generally encode four additional structural proteins, including the Spike proteins (1128-1472 amino acids), membrane protein (218-263 amino acids), envelope protein (74-109 amino acids), and nucleo-capsid protein (349-470 amino acids) [52] The N protein holds the RNA genome, and S, E, and M proteins together create the viral envelope [50]. Apart from this, these proteins may be involved in the entry of viral particles into the host cell after binding with host angiotensin-converting enzyme 2 (ACE-2) [53], promoting virulence, virus morphogenesis, assembly, budding, and folding of genomic RNA into the nucleo-capsid [54,55]. ACE-2 is a functional receptor hijacked by SARS-CoV-2 for cell entry, similar to SARS-CoV [56,57]. Briefly, it is a type 1 membrane protein expressed in the lungs, heart, kidney, and intestine mainly associated with cardiovascular diseases [58], and these human organs are vulnerable to SARS-CoV-2 [59]. Xiao and co-workers [60] report on the multiplication of virus in the mucosal epithelium of upper and lower respiratory tract and GI mucosa, while in other cases, patients present with heart injury, kidney failure, acute liver, and diarrhea, as non-respiratory symptoms $[37,61,62]$. Regarding respiratory symptoms, fever, coughing, and shortness of breath are the common symptoms of SARS-CoV-2 (https:/ / www.cdc.gov/coronavirus/2019-ncov/symptoms-testing/symptoms.html, Accessed date 22 February 2021), but olfactory and gustative disorders have also been reported in infected patients [63]. More recently, Wang and co-workers reported in a metanalysis that hypertension, diabetes, chronic obstructive pulmonary disease (COPD), and cardiovascular and cerebrovascular diseases are significant risk factors for COVID-19related mortality [64].

Regarding SARS-CoV-2 transmission, it is recognized as predominantly occurring through respiratory droplets, direct contact, and potential fecal-oral route transmission. In addition, it was recently underlined that SARS-CoV-2 can survive outside the body for a long time. For example, van Doremalen and co-workers [65] reported on the viability and stability of SARS-CoV-2 on different surfaces and found that the plastic and stainless-steel surfaces were more stable for SARS-CoV-2 than copper and cardboard, with the viable virus being detected for up to $72 \mathrm{~h}$ on these surfaces.

\section{Melatonin and Health: A Brief Overview}

Endogenous melatonin was proposed to be a potential key factor in promoting human health in the last century [66]. Indeed, describing its antioxidant properties raises the idea of supplementing with melatonin to protect brain health in the advanced aged population [66]. In the last two decades, numerous researchers have investigated the plethora of melatonin's actions protecting and regulating many aspects in humans [67]. There is, apparently, a lack of serious adverse effects after its supplementation [68]. Notwithstanding, a particular population should be monitored to clarify this relatively safe profile. Melatonin's pleiotropy, safety profile, and inexpensive cost have led researchers to investigate in humans the promising results elicited preclinically [69-71].

Mainly, among the most significant actions of supplemented melatonin described to date, we must highlight its antioxidant, free-radical scavenging, immunomodulatory, and anti-inflammatory activity, which makes melatonin a powerful tool in the treatment of any disease that involves one or more of these components. There is an increasing interest in melatonin against cancer; recent studies report a very promising oncostatic profile of melatonin in several types of cancer and associated effects that seem to enhance chemotherapy [72-76].

To reach a clinical therapeutic approach to all the pathologies that melatonin seems to improve, alone or in combination with other treatments, more economic support is needed. 
As melatonin is not patentable, it will probably not result in a high profit to companies; therefore, the clue may be to invest more public money, which will revert to better health in the population. Reportedly, melatonin seems to promote patient health and moreover save the lives of more critical patients.

\section{Melatonin Effects in COVID-19: A Clinic-Critical Perspective}

\subsection{Ongoing Clinical Trials on Melatonin Effects in SARS-CoV-2 Infection}

As mentioned above, melatonin is an endogenous non-patentable molecule; thus, clinical trials do not expect to obtain great economic benefits; indeed, most of the clinical trials developed are public-funded [69]. To date, there is a relevant lack of clinical trials concerning melatonin's therapeutic effects versus SARS-CoV-2's directly or indirectly related pathologies $[77,78]$. Clinical trials are mandatory to confirm the preclinical efficacy and safety observed [79]. Notwithstanding, the COVID-19 pandemic has launched several clinical trials to test doses, administration routes, and efficacy against SARS-CoV-2.

To our knowledge, 11 clinical trials are currently ongoing, registered in the Cochrane Library (ISSN 1465-1858) collection of databases (12 February 2021). Table 1 depicts a summary of the main characteristics of the ongoing trials. Only one clinical trial evaluates melatonin as a protective tool versus COVID-19; a daily dose of $2 \mathrm{mg}$ of melatonin is orally administered for 12 weeks to test whether melatonin may protect healthcare workers compared to the placebo group $[80,81]$. Interestingly, there is only one study on whether intravenous melatonin, administered to patients located in the Intensive Care Unit (ICU), can reduce mortality $[81,82]$. The other published protocol evaluates the efficacy and safety of $50 \mathrm{mg}$ of melatonin daily administered during seven days, compared to the standard therapeutic regimen [83]. As shown in Table 1, the rest of the trials test oral melatonin efficacy in mild or moderate patients; noteworthily, the administered doses go from 3 to $100 \mathrm{mg}$. As we previously pointed, selecting the correct doses is absolutely necessary to obtain reliable results $[18,84]$. Regarding the ongoing trials, very different profiles of melatonin's therapeutic value are being examined, from prevention to reducing mortality. These differences would probably make more difficult the overall analysis, whereas they may give a broad therapeutic profile. There are no results published to date; we are looking forward to analyzing and comparing results related to doses and administration routes, contributing to understanding the required doses and efficacy of melatonin against COVID-19. 
Table 1. Ongoing clinical trials with melatonin to treat SARS-CoV-2 infection.

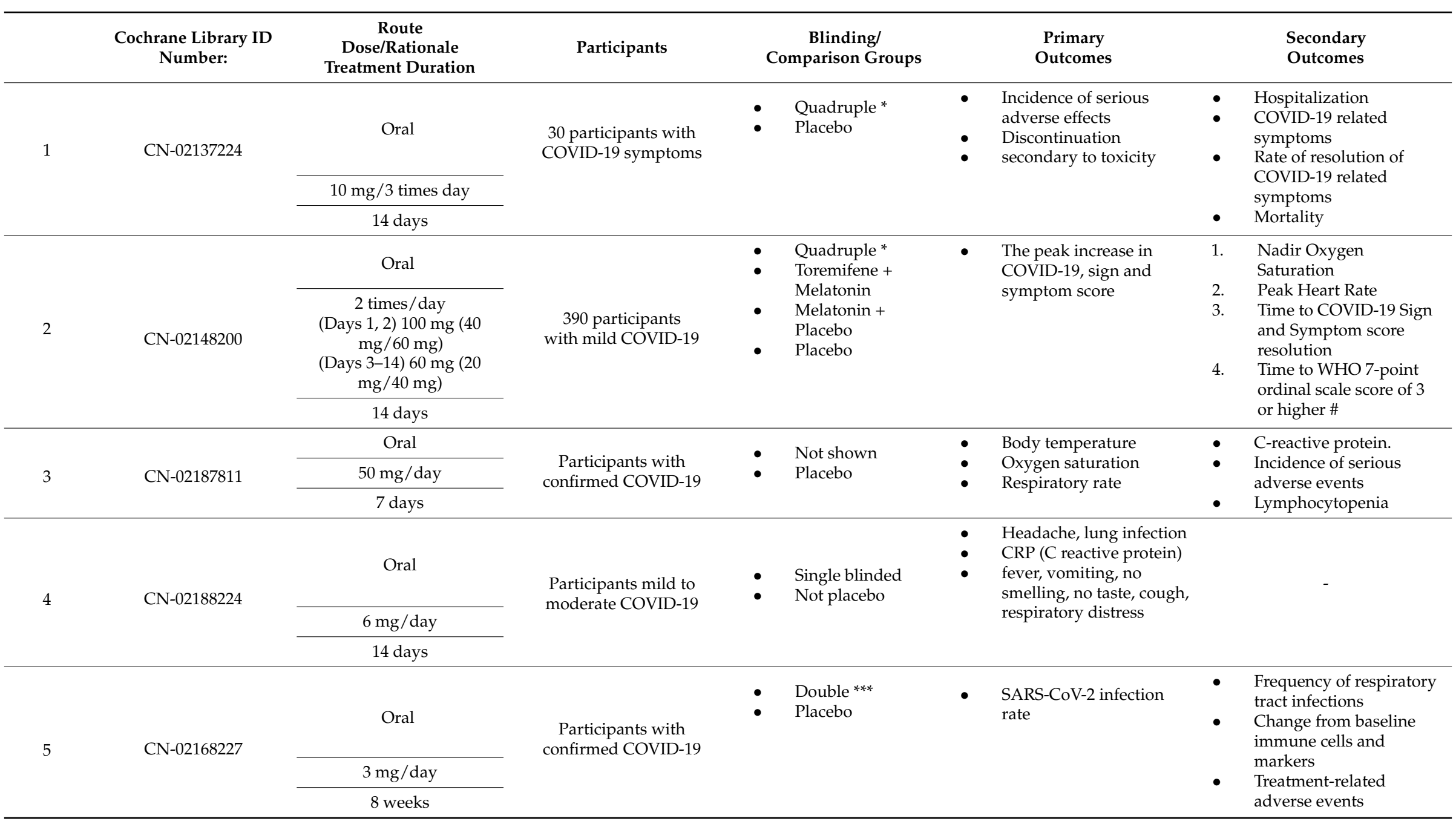


Table 1. Cont.

\begin{tabular}{|c|c|c|c|c|c|c|}
\hline & $\begin{array}{c}\text { Cochrane Library ID } \\
\text { Number: }\end{array}$ & $\begin{array}{c}\text { Route } \\
\text { Dose/Rationale } \\
\text { Treatment Duration }\end{array}$ & Participants & $\begin{array}{c}\text { Blinding/ } \\
\text { Comparison Groups }\end{array}$ & $\begin{array}{l}\text { Primary } \\
\text { Outcomes }\end{array}$ & $\begin{array}{l}\text { Secondary } \\
\text { Outcomes }\end{array}$ \\
\hline \multirow{3}{*}{6} & \multirow{3}{*}{$\mathrm{CN}-02148187$} & Oral & \multirow{3}{*}{$\begin{array}{l}150 \text { participants with } \\
\text { confirmed COVID-19 }\end{array}$} & \multirow{3}{*}{$\begin{array}{ll}\text { - } & \text { Triple } \\
\text { - } & \text { Placebo }\end{array}$} & \multirow{3}{*}{ - $\quad$ Symptom severity } & \multirow{3}{*}{ Symptom progressior } \\
\hline & & $10 \mathrm{mg} /$ day & & & & \\
\hline & & 14 days & & & & \\
\hline \multirow{3}{*}{7} & \multirow{3}{*}{ CN-02174361 } & Intravenous & \multirow{3}{*}{$\begin{array}{l}18 \text { participants with } \\
\text { confirmed COVID-19: } \\
\text { ICU critically ill adults } \\
\text { with acute hypoxemic } \\
\text { respiratory failure }\end{array}$} & \multirow{3}{*}{$\begin{array}{l}\text { - } \quad \text { Quadruple* } \\
\text { Placebo }\end{array}$} & \multirow{3}{*}{ - Mortality } & \multirow{3}{*}{ - } \\
\hline & & $\begin{array}{c}5 \mathrm{mg} / \mathrm{Kg} \text { b.w. / day / } \\
6 \mathrm{~h} \text { (maximum daily } \\
\text { dose } 500 \mathrm{mg} \text { ). }\end{array}$ & & & & \\
\hline & & 7 days & & & & \\
\hline \multirow{3}{*}{8} & \multirow{3}{*}{$\mathrm{CN}-02187792$} & Oral & \multirow{3}{*}{$\begin{array}{l}\text { Hospitalized participants } \\
\text { with confirmed } \\
\text { COVID-19 }\end{array}$} & \multirow{3}{*}{$\begin{array}{l}\text { - } \quad \text { Not shown } \\
\text { - } \quad \text { No placebo }\end{array}$} & \multirow{3}{*}{$\begin{array}{ll}\text { - } & \text { Need to oxygen } \\
\text { therapy rate } \\
\text { - } \\
\text { Rate of sleep and } \\
\text { depression } \\
\text { - } \quad \text { ICU time }\end{array}$} & \multirow{3}{*}{-} \\
\hline & & $36 \mathrm{mg}(18 \mathrm{mg} / 12 \mathrm{~h})$ & & & & \\
\hline & & 7 days & & & & \\
\hline \multirow{3}{*}{9} & \multirow{3}{*}{$\mathrm{CN}-02103276$} & Oral & \multirow{3}{*}{$\begin{array}{l}\text { - } \quad 450 \text { participants } \\
\text { Healthcare workers } \\
\text { not having a } \\
\text { previous COVID-19 } \\
\text { diagnosis }\end{array}$} & \multirow[t]{3}{*}{$\begin{array}{l}\text { - } \\
\text { - } \\
\text { Placebo }\end{array}$} & \multirow[t]{3}{*}{$\begin{array}{l}\text { - SARS-CoV-2 infection } \\
\text { rate }\end{array}$} & \multirow[t]{3}{*}{-} \\
\hline & & $2 \mathrm{mg}$ & & & & \\
\hline & & 12 weeks & & & & \\
\hline \multirow{3}{*}{10} & \multirow{3}{*}{ CN-02170332 } & Oral & Participants with & - $\quad$ Not blinded & \multirow{3}{*}{$\begin{array}{ll}- & \text { Heart rate } \\
- & \text { Number of } \\
\text { - } & \text { Coureaths /min } \\
\text { - } & \text { Rate of decline of lung } \\
\text { infection }\end{array}$} & \multirow{3}{*}{-} \\
\hline & & $40 \mathrm{mg}(10 \mathrm{mg} / 6 \mathrm{~h})$ & 19 & - $\quad$ No placebo & & \\
\hline & & 10 days & & & & \\
\hline
\end{tabular}


Table 1. Cont.

\begin{tabular}{|c|c|c|c|c|c|c|}
\hline & $\begin{array}{c}\text { Cochrane Library ID } \\
\text { Number: }\end{array}$ & $\begin{array}{c}\text { Route } \\
\text { Dose/Rationale } \\
\text { Treatment Duration }\end{array}$ & Participants & $\begin{array}{c}\text { Blinding/ } \\
\text { Comparison Groups }\end{array}$ & $\begin{array}{l}\text { Primary } \\
\text { Outcomes }\end{array}$ & $\begin{array}{l}\text { Secondary } \\
\text { Outcomes }\end{array}$ \\
\hline \multirow[t]{3}{*}{11} & \multirow[t]{3}{*}{ CN-02195959 } & Oral & \multirow{3}{*}{$\begin{array}{c}60 \text { participants with } \\
\text { confirmed COVID-19 and } \\
\text { moderate } \\
\text { pneumonia }\end{array}$} & \multirow[t]{3}{*}{$\begin{array}{l}\text { - } \quad \text { Double } \\
\text { - }\end{array}$} & $\begin{array}{ll} & \text { Recovery rate of } \\
\text { clinical symptoms } \\
\text { - } & \text { Oxygen saturation } \\
\text { - } & \text { Improvement of } \\
& \text { serum inflammatory }\end{array}$ & \multirow[t]{3}{*}{-} \\
\hline & & $50 \mathrm{mg}$ & & & parameters; C-reactive & \\
\hline & & 7 days & & & $\begin{array}{l}\text { protein, tumor TNF- } \alpha \text {, } \\
\text { IL- } 1 \beta \text {, and IL- } 6\end{array}$ & \\
\hline
\end{tabular}

${ }^{*}$ Quadruple $=$ Participant, Care Provider, Investigator, Outcomes Assessor; $* *$ Triple $=($ Participant, Care Provider, Investigator); *** Double binded $=$ Participant and Investigator Blinded; = Data not shown; b.w. = body weight \# WHO 7-point ordinal scale: a. - not hospitalized, no limitation of activities (or resumption of normal activity); b.-not hospitalized but a limitation on activities; c.- hospitalized, not requiring supplemental oxygen; d.-hospitalized, requiring supplemental oxygen (low-flow, e.g., nasal prong); e.-hospitalized, requiring non-invasive ventilation and/or high-flow oxygen; f.- -hospitalized, on invasive ventilation or ECMO; g.- - death 


\subsection{Sleep and Circadian Rhythms Dysregulation and COVID-19}

Interference with the pleiotropic beneficial actions of melatonin, particularly the inhibition of the secretory nocturnal peak by excessive lighting at dark time, the so-called "light-at-night idea" or LAN hypothesis [85], is potentially health-harmful and a risk factor for multiple disorders [86]. The promising profile of melatonin to treat COVID-19 is based on hindering several key steps for SARS-CoV-2 infectivity and the onset of disease, as well as on the improvement of respiratory and non-respiratory clinical features and the resynchronization of circadian disruption commonly found in affected individuals $[10,87]$. Specifically, nocturnal pineal melatonin is synchronized with an acute proliferation of hematopoietic stem and progenitor cells [88], and, accordingly, sleep deprivation led to disorders associated with chronic inflammatory tone. Therefore, we consider: (i) that the aged population represents the most vulnerable group to COVID-19 infection; (ii) the natural age-related decline of melatonin levels, (iii) that higher exposure of individuals to LAN also reduces melatonin levels and disrupts circadian rhythmicity. Therefore, if nighttime illumination is shielded from the patients in the intensive care units (ICU), it preserves higher levels of circulating melatonin [89] and stimulates immunity in COVID19 patients [90] and (iv) stress factors involved in the disruption of the sleep pattern such as depression, work overload, and long confinements with time watching TV and surfing the internet. Moreover, a recent report has postulated an association between increased physiological risk of COVID-19 infection and prolonged night-shift work [91]. Given this evidence, restitution of a regular circadian melatonin pattern would permit the protection of the most vulnerable workers under chronic light pollution. Therefore, we must optimize an adequate chronotherapeutic treatment following the body's circadian rhythms to improve the sequels, not only of COVID-19, but also of the consequences in the context of the pandemic situation [87]. In this regard, the chronobiotic agent melatonin regulates the sleep/wake cycle and other circadian rhythms and, even at high doses (50-100 mg p.o.), improves and prolongs the chronobiotic effect [87]. In fact, during the pandemic time, insomnia symptoms affected about $60 \%$ of the Italian population, and following the recommendations of five scientific societies, the melatonin prolonged release at the dose of $2 \mathrm{mg}$ was chosen as the pharmacological option in subjects $\geq 55$ years old over 13 weeks [92].

Delirium and sleep disturbances such as confusion, somnolence, and stupor were reported in almost $15 \%$ of hospitalized COVID-19 patients [93]. In the case of delirium, many factors trigger it; dysbalanced neurotransmitters, proinflammatory cytokines, tissue hypoxia, and sleep deprivation. In this sense, the administration of melatonin up to $10 \mathrm{mg}$ has been recommended in hyperactive delirium associated with COVID-19 infection in the ICU [94]. In this regard, between the considerations in the treatment of hyperactive or mixed COVID-19-associated ICU delirium, a high dose of the melatonin (10-15 mg enteric at night) was used to regulate the sleep-wake cycle and assists in the treatment of delirium in combination with Suvorexant [95].

The presence of comorbidities in COVID-19 patients such as diabetes, cardiovascular, or chronic kidney diseases can increase the risk of developing the severe disease [96]. Thus, individuals with diabetes present a decrease in melatonin production associated with high circulating glucose levels [97]. Therefore, when they are infected by SARS-CoV-2 must be important that maintain a good "sleep hygiene" to regulate their melatonin and glucose levels [98]. Interestingly, since melatonin may have beneficial effects for sleep disorders on COVID-19 outcomes, the obstructive sleep apnea could be another research field to examine its possible mechanistic pathways and its relationship with the effect of the COVID-19 pandemic [99]. Recently, it was also hypothesized that melatonin deficiency may predispose those autism spectrum disorder patients who have low melatonin output to contract COVID-19 [100]. 


\subsection{SARS-CoV-2 and Melatonin Target Proteins: CD147, DPP4, AhR, PAK1, and EGFR}

Refractory hypoxemia and myocardial injury are physiopathological conditions exhibited in COVID-19 patients under mechanical ventilation for the treatment of acute respiratory distress syndrome (ARDS), which is caused by SARS-CoV-2-induced acute oxidative erythrocytic damage. In this respect, erythrocytes are targeted by SARS-CoV-2 spike (S) protein through binding to CD147 receptors, which are widely expressed in many cell types such as hematopoietic and endothelial cells, leukocytes, and platelets. Furthermore, CD147 possesses a functional role in facilitating SARS-CoV infection, and it has been postulated as the primary SARS-CoV-2 receptor in a novel route of invasion [101]. Subsequently, disruption of $\mathrm{Ca}^{2+}$ homeostasis and alteration in the CD147-cyclophilin A signaling pathway may contribute to thrombotic events and inflammatory injury in the lung and heart failure [102]. Therefore, targeting CD147 to reduce inflammation and severity of the disease progression could be an interesting strategy to be addressed. In this context, melatonin has been used successfully to reduce cardiac damage through the blockade of the CD147 signaling pathway [103] and it may play an important role in diabetic COVID-19 patients [104]. Another proposed door for SARS-CoV-2 infection is the highly lung-expressed DiPeptidyl Peptidase-4 (DPP4) receptor, which has been found negatively regulated by melatonin in mice and in in vitro models of calcific aortic valve disease [105], suggesting the putative regulation of SARS-CoV-2 entry by the indolamine [106]. In this regard, the aryl hydrocarbon receptor (AhR) has attracted attention due to its multiple roles in the cocoordination of cellular internalization and pathophysiology associated with the infective process of SARS-CoV-2, particularly the "third cytokine storm" caused by induction of the indoleamine 2,3-dioxygenase (IDO)/kynurenine/AhR pathway [106]. AhR is activated by the discharge of inflammatory cytokines during the initial hyper-inflammatory phase that suppresses the endogenous immune response and facilitates the completion of the viral infective cycle, as reported in mouse hepatitis virus-infected cells [107]. Specifically, AhR activation stimulates gut permeability and microbiome dysbiosis [108], which increases TLRs' activators and reduces the production of the short-chain fatty acid, butyrate [109]. Butyrate and melatonin enhance mitochondrial acetyl-CoA and OXPHOS while acetyl-CoA coactivates the mitochondrial synthesis of melatonin. Thus, AhR activation increases gut permeability/dysbiosis and reduces gut butyrate and thereby the availability of mitochondrial melatonin, particularly in immune cells [106]. The reciprocal antagonism between AhR and melatonergic system is endorsed by AhR activation following viral invasion and the subsequent exhaustion of melatonin availability [77] as well as by the common occurrence of activated AhR and decreased pineal melatonin in comorbidities at high risk of fatal COVID-19 such as respiratory, cardiovascular, and metabolic disorders. It is therefore conceivable that melatonin administration may inhibit AhR and in this way drive part of its anti-inflammatory and immune-enhancing potential. Interestingly, regarding COVID-19, several nutraceuticals are functional antagonists of AhR and thereby their food intake has been postulated as a potential modulator of COVID-19 severity $[106,110]$. Then, the question that arises is: could melatonin be a relevant part of natural compounds capable of moderating the course of the disease in critically ill patients? The functional biology of the indoleamine and some preclinical data $[27,29,80-82,111-113]$ support an affirmative answer.

Molecular modeling tools facilitate theoretical prediction in the search for therapeutic targets that are vulnerable to SARS-CoV-2. Among them, chymotrypsin-like protease (Mpro) would be an interesting target to inhibit virus replication. It has been observed that the interaction between melatonin and Mpro, based on the docking energy results, highlights the therapeutic potential of melatonin by binding to viral protease Mpro [27]. In this same line, a detailed quantum-mechanical research predicted the capacity of melatonin to dock with SARS-CoV-2 proteins [26]. This interesting fact makes urgent further studies to incorporate melatonin in the COVID-19 treatment regime. Additionally, another interesting target enzyme to counteract the SARS-CoV-2 viability and progression is the major "pathogenic" kinase PAK1, whose malfunction induces inflammation, viral infection, and 
immuno-suppression; therefore, PAK1-blockers are considered to have an anti-coronaviral effect. Recently, melatonin has been related to an anti-PAK1 activity, which would evidence, one more time, the multifunctionality displayed by this indolamine [114].

Early observations have emphasized the epidermal growth factor receptor (EGFR) as a direct target in antiviral therapy; more precisely, EGFR signaling inhibition can prevent SARS-CoV-2 replication in the infected cells [115], and melatonin would be able to modulate growth factor receptor signaling activity inhibiting SARS-CoV-2 replication [116], mitigating the development of severe clinical symptomatology.

\subsection{Melatonin Impact from an Immune-Metabolic Perspective}

Numerous retrospective studies have shown that suffering from certain primary pre-existing pathologies facilitates symptomatic COVID-19 and increases the baseline of mortality [117-121]. In the middle of 2020, the Centers for Disease Control and Prevention announced that among COVID-19 patients, cardiac disorders and type 2 diabetes were the two most common predisposing conditions, with a participation of each of them around $1 / 3$ of diagnoses [122]. In addition, the need for hospitalization as well as the clinical course and death risk among comorbid patients were significantly poor compared with those without these primary pathologies. Indeed, from this perspective, chronic metabolic disease (obesity, type 2 diabetes and metabolic syndrome) as well as ischemic/non-ischemic cardiovascular and cerebrovascular pathology, along with chronic lung injury, are the most prevalent comorbidities that speed up the onset of COVID-19 and the worsening of the patients, having up to $\approx 10$-fold higher risk of death [123]. Abundant concordant data on the facilitation of multifactorial COVID-19 by these cardiometabolic disorders common in the elderly have been incessantly collected worldwide through the direct screening of large COVID-19 cohorts and longitudinal retrospective studies [117,124].

The resulting evidence of observational and clinical studies points out that all these closely related predisposing entities configure a pathological cluster involving the alteration of metabolic profile, the dysregulation of the innate immune reactivity, and low-grade chronic inflammation [125], which facilitates the cytokine storms and associated organ derangements. In this regard, the fact that inflammation and disturbances of energy metabolism can impair the immune response [57] had led to scrutinizing the immunological implications of obesity and the release of inflammatory factors by obese adipose tissue [126]. Specifically, the chronic low-grade inflammation associated with obesity was demonstrated as a conditional risk for metabolic disorders because macrophages recruited into adipose tissue result activated until their pro-inflammatory M1 phenotype, then releasing inflammatory mediators into the local and systemic environment [127]. On the other hand, cross interactions between innate immunity and metabolism facilitated the crystallization of "immunometabolism" [128], in whose conceptual framework the immune-metabolic interface is seen as a bidirectional control system [129]. Furthermore, immune response encompasses inflammatory activation, and for this reason, both processes must be approached as a unit of action. This integrative vision sheds light on the observation that metabolic and/or immunoinflammatory disruptions may contribute to prolonging hospitalization and/or to increasing lethality among COVID-19 patients [130]. Likewise, another relational consideration to annotate in the natural history of the current pandemic is the involvement of mitochondrial dysregulation in the onset of the pathological phenotype of COVID-19 and its primary predisposing disorders [131,132]. SARS-CoV-2 impairs the mitochondrial-associated antiviral signaling system (MAVS) which allows the virus to evade the surveillance of the host's innate immune system [132], as summarized in Section 4.6. In accordance with the latter, infections due to immunodeficiency are common in inherited mitochondrial disorders [45], clearly highlighting the pronounced effects that mitochondrial failure has on immune and inflammatory responses.

Low-grade basal inflammation and weakening of immune and antioxidant defenses are omnipresent in the elderly (inflammaging), metabolic syndrome abnormalities (metaflammation), and the spectrum of other pre-existing disorders behind the proclivity to COVID-19 
onset and aggravation. At the same time, the aging and chronification of nosological entities that coexist with COVID-19, particularly those exhibiting insulin resistance, are accompanied by a progressive fall in circulating melatonin [132-134]. It is noteworthy that clinical trials and studies with animal models indicate that supplementation with melatonin may be a valid strategy to tackle symptomatology and halt the progression of COVID-19 [134-136], perhaps because the indoleamine helps to counteract the debilitating phenotype of aging [137] and predisposing pathologies [133,138,139]. In this regard, based on the orchestration of endocrine, paracrine, and autocrine responses, melatonin may be considered a smart controller of the innate and adaptive immunity [140] and inflammation [141], a neuroimmune-endocrine regulator [142] that collaborates with the maintenance of the internal environment and the mitigation of cell/tissue perturbations. Consequently, the homeostatic mediation of melatonin must be understood as a cell protector endowed with multiple restorative capacities of metabolic and immunoinflammatory disturbances and with particular potential utility in respiratory and lung viral infections [142]. Recently, mitochondria have revealed themselves as the core target of melatonin activity $[143,144]$, and hence, normalization of mitochondrial function and reduction of nitro-oxidative stress are the backbone of pleiotropic action performed by the indoleamine therein [145]. Indeed, melatonin protects mitochondria against glycolytic energy metabolism instilled by SARS-CoV-2 [146]. In this way, indoleamine reduces oxidative stress and contributes to preventing hyper-inflammation and the innate immune exacerbation that led to the feared storm of cytokines. Furthermore, the return to OXPHOS replenishes the mitochondrial pool of acetyl-CoA, which is needed as co-substrate for the in-situ synthesis of the indoleamine, thus closing the virus-dependent disruption of mitochondrial melatonin. Consistent with all of the above, in different experimental settings and clinical trials, melatonin has shown remarkable capacities in the normalization or attenuation of insulin resistance, inflammation, nitro-oxidative stress, and chronodisruption of peripheral oscillators [134,141]. In addition, melatonin signaling pathways have an extensive influence on glucose homeostasis and energy metabolism [147]. Correspondingly, the administration of complementary melatonin has demonstrated successful outcomes in the management of diabetes and metabolic syndrome [148-152], obesogenic chronodisruption [153], and the other specific traits associated with cardiometabolic pathologies typical of aging and prevalent among severely ill COVID-19 patients [134].

Chronic metabolic disease and cardiovascular and cerebrovascular disorders have reached an epidemic dimension in our era as an accelerated aging spread in industrialized countries and the hypokinetic-hypercaloric/lipidomic western lifestyle has become hegemonic in much of the world. The unfortunate connection between the pathological phenotype of these predisposing conditions and the increased vulnerability of such a high number of people to the most detrimental outcomes of COVID-19 is determinant in the colossal health threat, unprecedented in recent history, posed by this pandemic. Melatonin may come to the rescue of this dire situation, ameliorating the pathological coordinates of primary predisposing comorbidities and thereby providing countermeasures for the avoidance of highly diseased COVID-19 patients. Based on this background, supplementation of the internal pool of the powerful antioxidant, anti-inflammatory, and immunostimulant melatonin are a low-cost, low-toxicity and, more importantly, potentially efficient strategy to strengthen homeostasis mechanisms, achieve so-called "healthy aging" [134], and overcome the array of cardiometabolic complications that negatively impact the prognosis of COVID-19.

\subsection{Melatonin and Inflammaging in the Context of COVID-19}

The natural history of disease in modern Medicine includes an inflammatory component that is not merely epiphenomenal since the conceptualization of molecular pathogenesis gains consistency with the incorporation of cellular and signaling mechanisms of inflammatory response. Moreover, in many gnoseological entities such as sepsis or viral infections [154], destructive high-grade inflammation plays a leading role in the 
expression of pathological phenotype that is critical to control for ameliorating adverse prognosis. This is the case of COVID-19, in which the severe disease progression comes from a life-threatening immune-inflammatory cycle orchestrated by the overreaction of innate antimicrobial immunity and inflammation mechanisms activated by the presence of viral proteins [155]. The epidemiological picture of the current pandemic shows that people highly susceptible to infection and severe prognosis share a turn-on immune system and chronic inflammation [156], as people with primary comorbidities and/or frail immunocompromised elderly people over 65 , especially male [157], who account for $\sim \frac{3}{4}$ of seriously ill COVID-19 patients [123]. To such an extent, the inflammation is decisive for the outcome of COVID-19 [158]. Thus, the fatal prognosis of hyper-inflammation and target organs in COVID-19 depends on the immune overreaction rather than on pathogenmediated damage [159]. Indeed, patients in early COVID-19 stages display innate immune up-regulation, lymphocytopenia, and elevated serum content of cytokines (mainly TNF- $\alpha$, IL-6), chemokines, and other chemoattractants [160], along with reduced launch levels of antiviral type I and III interferons [161], globally leading to an auto-inflammatory loop.

Once SARS-CoV-2 penetrates lung tissue targeting the conserved membrane Angiotensin Converting Enzyme-2 (or ACE2) receptors [162], the renin-angiotensin-aldosterone system is gathered and the NLRP3 inflammasome and the highly inflammatory cell-death associated pyroptosis are activated [163]. Afterward, recruited phagocytes release local pro-inflammatory factors and initiate T- and B-cell-dependent immune responses. Hence, different subtypes of effector T-cells or regulatory activated $\mathrm{CD}^{+} \mathrm{T}$-cells eliminate epithelial infected cells or secrete exaggerated amounts of pro-inflammatory cytokines and chemokines into the bloodstream. This storm of cytokines induces the apoptosis and necrosis of affected cells, the release of their cellular contents, vascular endothelial hyper-permeability, and ultimately new inflammation inputs, which, in the interim of approximately one week, will devastate cells and tissue until the complete disruption of respiratory physiology [164].

Based on the aforementioned precedents on COVID-19 pathogenesis, the blockade of excessive cytokine release by targeting some of its critical triggers would avoid the multiple organ damage/failure and reasonably palliate the adverse outcome of the disease, as well as contribute to implementing effective curative strategies. In this regard, melatonin stands out as one of the best-positioned intervention therapy options to return to equilibrium the critical gears of uncontrolled immune inflammation. Although the current investigation into direct protection of ACE2 by melatonin is inconclusive [165], the evidence of its anti-inflammatory capacity is indisputable. Noteworthily, melatonin modulates inflammation as a hormesis-like process, activating moderate pro-inflammatory mechanisms in the course of the homeostatic immune response to intruder pathogens and contrarily stopping inflammatory mechanisms in contexts of hyper-inflammation, attenuating circulating cytokines and pro-inflammatory effectors [106]. For this reason, melatonin may ameliorate the exacerbated host inflammatory response and thereby prevent the irreversible pulmonary fibrosis and chronic respiratory damage of severely ill COVID-19 patients [10,166], as the indoleamine has demonstrated in experimental studies $[167,168]$. This damped response rests on positive modulation of anti-inflammatory cytokines such as IL-10 and attenuation of pro-inflammatory ones, such as IL-1 $\beta$, IL-6, IL-8, or TNF- $\alpha$ exerted by melatonin [169]. A similar rationale supports the use of melatonin to treat gut complications caused by hyperinflammation and exacerbated innate immune response against SARS-CoV-2 [170]. The combined anti-inflammatory and immunomodulatory capabilities of pleiotropic melatonin endow it with an extraordinary potential to prevent the gastrointestinal complications associated with SARS-CoV-2 infection [170]. In addition, the reciprocal interaction between the gut microbiome and pulmonary physiology, termed the "gut-lung axis", provides microbiota with a relevant role in the immune homeostasis and the deadly recurrent ARDS in COVID-19 [171]. Melatonin reduces gut membrane permeability and is active in the chronoregulation and maintenance of a healthy balanced gut microbiome [172]. A recent work has elucidated the immunomodulatory importance of melatonin, both pineal and systemic, in COVID-19 severity, mediated by a complex myriad of factors, including the 
alpha 7 nicotinic acetylcholine receptor from lung epithelial and immune cells or the gut microbiome-derived and epigenetic regulator butyrate [173]. A noticeable meta-analysis of the anti-inflammatory capacity of melatonin administration has recently confirmed, based on 13 studies and a global cohort of 749 people, the reduction of TNF- $\alpha$ and IL-6 levels [174], suggesting that it would have a similar effect on COVID-19 patients. However, the initiation of melatonin supplementation must be carefully addressed to ensure its antiinflammatory potential [31]. However it is hypothesized that the anti-inflammatory activity of melatonin is mainly achieved by orchestrating the suppression of toll-like receptor (TLR) signaling [175], the inhibition of the multiprotein platform inflammasome promoter NLRP3 (Nucleotide-binding Oligomerization Domain (NOD)-Like Receptor Pyrin domain containing 3) [176], and the blockage of the nuclear translocation of the NF-KB [76]. The result of binding viral proteins and/or genomic ssRNA by TLR/PAMPs would be the recruitment of the receptor-ligand complexes and the activation of apoptosis, lysosomal autophagy, and inflammasome-induced pyroptosis for the clearance of the virus [166]. Additionally, self-components from the autolytic processes activated, and particularly those released from stressed suboptimal mitochondria, initiate another immune-inflammatory cascade known as the "secondary cytokine storm". These concatenated massive cytokine releases give rise to the fearsome continuous immune-inflammatory process that causes the extensive tissue and organ damage of the critical COVID-19 phase. In this scenario, melatonin may presumably prevent the secondary cytokine storm and associated hyper-inflammation of COVID-19. Different disease models have shown melatonin repressing pro-oxidant TLR2- and TLR4-mediated signaling cascades in the inflammatory phenotypes of ovarian cancer and coronary artery disease [175]. Moreover, TLR4 is commonly associated with the oxidative stress-sensitive NK- $\mathrm{kB}$ pathway and the triggering of inflammation. Therefore, in the context of COVID-19, the potential involvement of melatonin in the control of hyper-inflammation through the genetic and/or mechanistic inhibition of certain prooxidant TLRs is extremely consistent, as reported in some viral processes. Following these precedents and regarding COVID-19 moderation, in silico-based force-fields, the modeling of putative SARS-CoV-2 mRNA-TLR binding interactions has shed light on the probable activation of the TLR-dependent downstream inflammatory pathway by several mRNAs of SARS-CoV-2 [177], opening the way to melatonin intervention.

Melatonin also has the ability to prevent the activation of NLRP3 inflammasome in respiratory disease and other disturbances. This is the case of acute lung injuries such as sepsis or pneumonia, in which melatonin has been reported to reduce lung inflammation by selectively inhibiting the assembly of the NLRP3 inflammasome [178,179]. Excessive inflammation is a clue factor in the negative evolution of COVID-19 and other viral infections. Accordingly, it would make perfect sense that the NLRP3 complex directly or indirectly drives the hyper-inflammatory cascade associated with the explosive cytokine storm syndrome, as a large body of recent evidence points out [180]. Melatonin directly targets NLRP3 and precludes the activation of the inflammasome complex, enabling it to modulate inflammation. Therefore, it seems reasonable to launch the clinical trials with supplemental melatonin in the acute interval of ARDS, the height of hyper-inflammation of COVID-19, as recently proposed [25,31]. Nevertheless, direct experimentation is required on this matter to screen the auxiliary treatment of COVID-19 by the interference of inflammasome activation and open the alternative intervention routes and treatment schedules that are so urgently needed.

In addition to the above findings, a hypothetical method that adds to the therapeutic possibilities of melatonin to moderate the inappropriate inflammatory response of COVID19 is the control of Nuclear Factor (erythroid-derived 2)-like 2 (NRf2), a pivotal regulator of antioxidant responses that induce phase-II antioxidant enzymes [29]. Nrf2 is in a close mechanistic relationship with sirtuin 1 and NK- $\mathrm{BB}$, whose close coordination in the protection from acute lung disease and acute respiratory distress syndrome has been raised as possible [181]. On a related topic, an association is observed between the cytokine release syndrome and the elevation of the gene expression modulator miR155, which also 
appears to be raised in the high-risk comorbidities of SARS-CoV-2 [106]. miR155 sustains the upregulation of cytokines in immunocytes and, in this regard, the demonstrated ability of melatonin to drop its levels [182] highlights the potential of this indoleamine in improving the clinical expression of COVID-19. Furthermore, the close relationship between melatonin and miR155 in different cell types is an additional indication that melatonin can be more efficient in the control of this transcriptional regulator than specific miR155-targeted drugs [106]. These studies provide strong support that exogenous and/or endogenous melatonin acts on inflammatory cascades and may correct the pro- vs. antiinflammatory inputs in the course of mitigating hyper-inflammation. There is therefore enough evidence to take very seriously the adequacy of the functional biology of melatonin to the pathophysiology of COVID-19.

In parallel with activation of phagocytes and intracellular PRR/TLR pathways of innate immunity, melatonin cross-activates proliferation and the maturation of natural killer cells as well as T and B lymphocytes in the bone marrow and peripheral tissues [166]. These actions could help to deploy the adaptive cell/humoral immune response through specific antibodies fitted to the idiosyncrasy of SARS-CoV-2 and improve the detrimental outcome of COVID-19 patients. A proof-of-concept of the immune-endocrine axis and the role of melatonin in bidirectional communications is the production of melatonin in immune cells [183] and the association of inflammatory tone with nocturnal melatonin depletion [184]. The reinforcement of T-cells is relevant to the role attributed to melatonin against COVID-19 because in many asymptomatic patients or with mild symptoms, a low level of humoral antiviral response has been detected and, in contrast, a strong response mediated by $\mathrm{T}$ lymphocytes [45].

Melatonin has also revealed beneficial for shielding oxidative stress and inflammation generated by an excess of reactive oxygen and nitrogen species (RONS) in acute lung parenchyma injury and ARDS, as well as in the respiratory stress and delirium arising from intubation and assisted ventilation of patients under intensive care [185]. Particularly, circulating IL-6, the central milestone of the cytokine storm, is an independent predictor of lung injury and the severity of pneumonia in COVID-19 patients [158]. Critical COVID-19 patients present advanced inflammation, dyspnea, severe septic hypoxemia, and pneumonia that reduce breathing and respiratory efficiency and lead patients to long periods of intensive care and eventually intubation. The high pressure of oxygen in forced mechanical ventilation conditions produces oxidative stress and an epithelial-mesenchymal transition leading to fibrosis, thus making very plausible the role that melatonin could play in the management of this clinical phenotype. In addition, melatonin protects alveolar surfactant from peroxidation by infiltrating neutrophils, thus preventing the obliteration of pulmonary ways [186] and thereby improving the gas exchange in seriously diseased COVID-19 patients.

\subsection{Mitochondrial Disruption Aggravating COVID-19}

Mitochondrial dysfunction, such as depletion of energy generation (OXPHOS deficiency), RONS overproduction, or inhibition of membrane potential (membrane leakage), among others, is increasingly associated with the molecular pathogenesis of a growing number of diseases, including those neural, muscle, and endocrinopathies severely incapacitating and specifically denominated "mitochondrial disorders" [187]. Many viral infections may affect mitochondrial architecture and dynamics and interfere, either inducing or inhibiting their important spectrum of biochemical functions $[188,189]$. However, regarding COVID-19 pathogenesis, mitochondria have not focused enough interest, in spite of the fact that perturbation of this integrative center of energy and metabolism hinders an adequate host-pathogen defense [190]. It must be taken into account that immune response has a strong demand for biosynthetic and mitotic activities, which are strongly dependent on energy produced by mitochondria. In connection with immune interference, acute COVID-19 patients present subsets of dysfunctional T-cells with dysmorphic mitochondria exhibiting altered ultrastructure and cytochrome c release [191]. In agree- 
ment with this rule, recent studies of the global SARS-CoV-2 interactome map reported high-confidence protein-protein interactions that demonstrated the putative targeting of host mitochondria proteins by viral components [192,193], including the innate immune system. Similarly, computational machine learning models have predicted the preferential enrichment of genomic SARS-CoV-2 RNA in the mitochondrial matrix and nucleolus of the host [194]. Overall, SARS-CoV-2 may target mitochondria and disrupt their internal organization and functionality [195], so energy failure and increased RONS generation in the suboptimal stressed mitochondria determine the hyper-inflammation that aggravates the COVID-19 outcome [196]. With regard to this, the analysis of public transcriptome datasets has led to finding a transcriptional signature induced by SARS-CoV-2 that includes the induction of OXPHOS genes [197]. Analogously, transcriptome profiling of human lung cancer cells infected with SARS-CoV-2, influenza A virus, or MERS-CoV (subsequently validated on human nasopharyngeal specimens positive for COVID-19 and their control counterparts) revealed that SARS-CoV-2 can specifically disrupt inflammatory responses and mitophagy/autophagy machinery, as well as deregulate a myriad of genes linked to inflammation and cytokine signaling, cell cycle, RONS balance, mitochondrial organization, and translation [198]. These proof-of-concept studies demonstrate that "mitochondrial hijacking" to hinder the innate immune mechanisms and favor self-destructive hyper-inflammation and sepsis is strategic for viral infection [190]. Furthermore, the worse outcome and death risk of COVID-19 in males [199] has been related, among other unanswered hypotheses, to the sexual hormone-dependent dimorphism of mitochondria [200] and to sex-linked differences in immune response due to their matrilineal inheritance [201]. Of note, the apparent superiority in stress resilience of maternal mitochondria has been related to their greater performance in the production of melatonin [166].

Viruses evolved strategies to hijack mitochondrial machinery and evade the recognition by the viral sensor (RIG-I)-like receptors (RLRs). Once entering the cell, key intracellular receptors housed in the mitochondrial outer membrane named MAVS signalosome [202] usually recognize viral antigens and activate the defense system to restrain microbe invasion. In the case of SARS-CoV-2, it has been hypothesized that viral protein ORF9b would suppress MAVS downstream signaling (through Tumor necrosis actor Receptor-Associated Factor (TRAF) 3 and TRAF6) and thereby the innate immunity and the related release of interferons could lose robustness [190]. In accordance with this prediction, it has been recently demonstrated that ORF9b from SARS-CoV-2 colocalizes on mitochondria and interacts with TOM70 protein in the outer membrane to suppresses IFN-I responses [203], and ORF9c interacts with complex I of the respiratory chain [204]. ORF9b may promote virus replication by inhibiting the apoptotic destruction of infected cells and by supporting their survival and viability through induction of mitochondrial elongation and fusion. In short, ORF9b disarticulates mitochondrial processes, such as mitophagy, which increases the oxidative stress, allowing inflammation and the mitochondrial complement to be kept fully functional [195]. Moreover, the hijacking of mitochondria deteriorates their structure, increases their permeability and the release of mitochondrial materials to the cytosol, and contributes to inflammation. In addition, SARS-CoV-2 depends on mitochondria (as well as endoplasmic reticulum and Golgi apparatus) to ambush itself, assemble the membraneassociated replication complexes, and put the genetic and biochemical machinery of the organelle at the service of its own replicative and immune escape requirements [194].

Recent findings have shown that melatonin is abundant and may be enzymatically synthesized in mitochondria [205-207]. Moreover, cellular and mitochondrial membranes are embedding melatonin transporters that allow bidirectional mobilization and concentration of the indoleamine [208]. Therefore, mitochondria can take extracellular melatonin when circulating or cerebrospinal fluid levels rise above normal [209]. All this evidence points out that this "second pool" of the indoleamine [165] is abundant because high levels are needed for the homeostasis of mitochondria. SARS-CoV-2 can dramatically manipulate the mitochondrial biochemistry, shifting their energy profile from OXPHOS to an abnormal preponderance of aerobic glycolysis ("Warburg effect"). This change maxi- 
mizes ATP production and provides immune cells with energy and resources to sustain their intense phagocytic activity and massive release of cytokines [210]. In this regard, night-time pineal melatonin is active, resetting the immune system and strengthening defense responses through OXPHOS optimization [210]. Therefore, the exogenous melatonin should revert the preponderance of cytosolic glycolysis induced by SARS-CoV-2 and promote the switching to OXPHOS. Supplemental melatonin may improve mitochondrial metabolism and provide the acetyl-CoA for the in situ synthesis of the indoleamine [146]. Consequently, targeting glycolysis and resetting the energy metabolism of mitochondria to healthy interval exogenous melatonin may help to reverse the impact of SARS-CoV-2, especially the cytokine storm syndromes and ulterior devastating immune-inflammatory exacerbation. In this manner, the most severely detrimental COVID-19 symptomatology would be relieved [146].

Mitochondria are active sources of melatonin and also producers of large amounts of RONS and other free radicals. Nevertheless, melatonin preserves the homeostasis of mitochondrial structure and functionality thanks to its competence in scavenging RONS excess (melatonin binds up to 10 free radicals per molecule; [211]), which protects them from apoptosis and enhances their anti-oxidative systems [143]. Viral respiratory processes heal with hyper-production of free radicals and nitro-oxidative stress, leading to inflammation and tissue damage [212], hence the interest in the direct and indirect scavenging activity of melatonin as well as in the therapeutic relevance of its anti-inflammatory properties [213]. RONS are microbiocidal in origin and therefore are buffered by mitochondrial antioxidant systems into the physiological range [214]. Conversely, RONS excess produces chemical insults on cell macromolecules and induces the highly inflammatory mitochondrial lytic pyroptosis. In this regard, the ability of melatonin to quench the overload of RONS and mitigate nitro-oxidative stress is another reason to be confident in its therapeutic potential against the COVID-19 pandemic, as repeatedly postulated [31], since the protection deployed on mitochondrial membrane potential, RONS homeostasis, and energy metabolism is effective to orchestrate an innate immune response in the intensity range more lethal for SARS-CoV-2.

Dysregulation of ion trafficking across mitochondrial channels is a major cause of pathophysiology, as occurs with iron in COVID-19 in which a clear correlation between serum hyperferritinemia and disease severity as well as between ferritin blood load and circulating IL-6 cytokine have been reported $[57,215]$. At this point, the action of melatonin in moderating cytokine secretion, preventing oxidative stress, and reducing the hyperferritinemia associated with hemodialyzed patients under inflammation [216] supports the dual proactive role of melatonin in COVID-19 as an anti-inflammatory and regulator of iron overload.

Given the short history of SARS-CoV-2 in science, many important details of its biology remain unknown. Soon, these lags will be elucidated, and new approaches to reducing infectivity, neutralizing tropism, cancelling spread-out, and overcoming the health issue of COVID-19 will be available. The natural history of COVID-19 is still being written, but an undoubted fact emerges from the chapters already known: SARS-CoV-2 enhances self-replication, impairing mitochondrial biosystems until defective autophagy and mitophagy, the deterioration of proteostasis, the depletion of OXPHOS in favor of anaerobic glycolysis, the overproduction of RONS, and the subsequent nitro-oxidative stress. All these impairments ultimately damage peripheral target organs such as the lungs, gut, or brain [217] and eventually lead to death. This central role played by mitochondria makes them strategic in the infective cycle of SARS-CoV-2 and therefore putting their biochemical capacities into play is one of the best options to treat COVID-19. Regarding this, mitochondria are active factories of melatonin production and one of the main operational centers of the indoleamine. In view of this, it seems clear that this molecule is a leading actor in the orchestration of immune, metabolic, oxidative, and inflammatory responses driven and coordinated by mitochondria. 


\subsection{Melatonin in Adjuvant Therapy Combination Against SARS-CoV-2 Infection}

Evidence in the melatonin field has suggested its use as a combination treatment with the possibility of enhancing the therapeutic activity of different drugs and/or reducing the possible side effects when they are administered, which would suggest interesting beneficial perspectives. Additionally, melatonin has vasodilation effects on pulmonary arteries based on its antioxidant and anti-inflammatory capacities, and this vasoactive potential is another favorable support for adjuvant prescription of indoleamine to pandemic-affected individuals [218]. In this sense, adjuvant melatonin administration in combination with the current low-efficacy standard antiviral treatments promotes important improvements in symptomatology, clinical outcome, and support requirements of COVID-19 patients [113,219], in part because different molecules have different targets and mechanisms of action. Thus, melatonin can reconcile the need for delivering mechanical respiratory support in some acute COVID-19 patients and the damage inherent in forced ventilation. In accordance with its affordability and expected accuracy, much scientific press is echoing the formidable therapeutic and/or prophylactic expectations of adjuvant melatonin for the treatment of COVID-19 patients, alone or in synergistic combination with other natural products that share its nuclear receptor and signaling profile, such as vitamin D [220]. More recently, it has been suggested that the supplementation of vitamin $\mathrm{D}$, zinc, melatonin, and possibly additional nutraceuticals could reduce the risk and aid control of COVID-19 and a range of other viral infections [221]. Therefore, in the context of "antioxidant therapy", a cocktail with antioxidant supplements such as vitamins $\mathrm{C}$ and E, $\mathrm{N}$-acetylcysteine, and melatonin in combination with the hemorrheologic agent pentoxifylline could contribute to the mitigation of the aggressive and lethal development COVID-19 [222]. Likewise, given the rich evidence that this extensive literature compiles and the international prestige of some of the personalities that bona fide endorse this clinical strategy, it is difficult for us to find resounding words and a new convincing voice to persuade public health dealers and professionals about the urgency of undertaking standardized clinical trials. Additionally, melatonin upregulates B-cell proliferation and therefore potentiates refined humoral immune responses [166] and modulates positively the innate and adaptive immunities as a vaccine adjuvant [223]. Noticeably, the immunomodulatory action as adjuvant of melatonin may enhance the effectivity of vaccination in immunocompromised individuals, such as aged people and patients with comorbidities, who are at great risk of lethal COVID-19. Specifically, melatonin pre-treatment can increase the intensity and temporal coverage of the immune response, enhancing natural killer and $\mathrm{CD} 4^{+}$cells in addition to reducing the side effects of vaccination [23,32]. Melatonin has also been documented targeting the activity of CD147, which takes part in the cytokine storm that causes inflammatory injury in the lung [101]. In this context, and considering the involvement of CD147 S glycoprotein in RONS production and inflammatory responses, supplemental melatonin has been proposed as a possible adjuvant to ameliorate the COVID-19 symptomatology and the side-effects associated with the current repurposed therapeutics, especially among frail, elderly, and immune-compromised patients [104]. Furthermore, using a systems biology and artificial-intelligence-based approach to reducing the severe pulmonary complications caused by SARS-CoV-2, the combined action mechanism of melatonin and pirfenidone predicted that they may modulate the high levels of proinflammatory chemokines and cytokines, improving the pathophysiology of COVID-19 patients [224,225]. In this same line, using a network-based methodology for systematic identification of putative repurposable drugs was identified as a combination of mercaptopurine plus melatonin, which may synergistically inhibit multiple cellular targets in the infectious process of SARS-CoV-2 [24].

Consequently, in the pressing context created by the COVID-19, we herein propose that melatonin upregulation or its adjuvant administration with current repurposed pharmacological prescriptions can be pivotal to achieving more effective treatments to curb the current spread of disease and improve the clinical management of patients. As other authors have emphasized, in the worst scenario, "melatonin is not yet guaranteed as an effective treatment, it likely would be useful and is unlikely to do any harm" [165], and we 
will have nothing to regret. On the contrary, in the probable case that it provides part of therapeutic expectations demonstrated in other pathological scenarios, the contribution of ancient melatonin to global public health in this dramatic sanitary alert will be historical.

This preliminary evidence points out the prophylactic and/or supportive therapeutic potential of adjuvant melatonin in respiratory and non-respiratory complications of COVID-19. Specifically, self-limitation or abrogation of the local and systemic inflammatory mechanisms account for the multiply reported benefits of melatonin in respiratory disorders with pulmonary involvement [226], and it could be analogously assumed against the lung damage in COVID-19 patients. The initial backgrounds, therefore, highlight the rationale for undertaking with no delay observational studies of large-scale cohorts, as well as randomized clinical trials, to validate the clinical effectivity of the indoleamine in reducing symptoms and/or its prophylactic utility $[25,29]$. In the absence of effective drugs against SARS-CoV-2 and palliative therapies for COVID-19 and taking into consideration the difficulties encountered by vaccination against previous viral processes [18], it is time to implement other therapy options. In this regard, the combination of current treatment protocols with multitasking melatonin may be the gold standard that humanity imperatively needs to fight COVID-19 and that science is desperately searching for.

The therapeutic potential of melatonin to fight COVID-19 is very wide, as we have depicted along point 4 . To summarize the properties, we elaborate in Table 2.

Table 2. Melatonin potential effects against COVID-19 disease.

\begin{tabular}{|c|c|}
\hline COVID-19 Actions & Melatonin Potential Properties \\
\hline $\begin{array}{l}\text { Sleep and circadian rhythms dysregulation. } \\
\text { Melatonin deficiency = higher risk }\end{array}$ & $\begin{array}{ll}\text { - } & \text { Resynchronization of circadian disruption } \\
{[10,87,91] .}\end{array}$ \\
\hline $\begin{array}{l}\text { Refractory hypoxemia and myocardial injury. } \\
\text { Thrombotic events and inflammatory injury in } \\
\text { the lung and heart failure. }\end{array}$ & $\begin{array}{l}\text { Binds viral protease Mpro [27]. } \\
\text { Exerts anti-PAK1 activity [114]. }\end{array}$ \\
\hline $\begin{array}{c}\text { Low-grade basal inflammation, weakening of } \\
\text { immune and antioxidant defenses, and } \\
\text { metabolic syndrome abnormalities are } \\
\text { predisposing } \\
\text { conditions to COVID-19 aggravation. }\end{array}$ & $\begin{array}{l}\text { Controls the innate and adaptive immunity } \\
\text { [140] and inflammation [141]. } \\
\text { Regulates neuroimmune-endocrine system } \\
\text { [142]. } \\
\text { Reduces oxidative stress and contributes to } \\
\text { preventing hyper-inflammation and innate } \\
\text { immune exacerbation [143-145]. }\end{array}$ \\
\hline $\begin{array}{c}\text { Obesity, cardiac disorders, and type } 2 \text { diabetes } \\
\text { increase mortality. }\end{array}$ & $\begin{array}{l}\text { Melatonin-related signaling pathways have an } \\
\text { extensive influence on glucose homeostasis } \\
\text { and energy metabolism [147]. } \\
\text { Improves diabetes and metabolic syndrome } \\
\text { [148-152], obesogenic chronodisruption [153], } \\
\text { and other traits associated with } \\
\text { cardiometabolic pathologies [131,134]. }\end{array}$ \\
\hline Life-threatening immune-inflammatory cycle. & $\begin{array}{l}\text { May ameliorate the exacerbated host } \\
\text { inflammatory response }[10,18,25,31,169,186] \text {. }\end{array}$ \\
\hline Mitochondrial disruption. & $\begin{array}{l}\text { May improve mitochondrial metabolism and } \\
\text { reset energy metabolism }[31,146,210]\end{array}$ \\
\hline
\end{tabular}

\section{Melatonin: From Regulatory to Safe and Effective Interventions in COVID-19}

In the European Union (UE), the European Medicines Agency (EMA) melatonin first approved Circadin, $2 \mathrm{mg}$ of melatonin, for medical use in adults over 55 to treat insomnia in 2007 (EMA/273802/2010); to date, two registered medicines contain melatonin as an active substance, Circadin and Slenyto (EMA/570422/2018). Circadin contains $2 \mathrm{mg}$ melatonin tablets, and it needs a prescription. Slenyto has been authorized for treating insomnia in children and adolescents (from 2 to 18 years old) who have autism spectrum disorder or Smith-Magenis syndrome (SMS) (a condition that can lead to learning difficulties). While the recommended dose is $2 \mathrm{mg}$, it is available as tablets from 1 to $5 \mathrm{mg}$. This treatment 
should be supervised at least every six months and only if it is beneficial. Nonetheless, melatonin is designated as an orphan medicinal product for six rare diseases: treatment of perinatal asphyxia, SMS, necrotizing enterocolitis, neonatal sepsis, neonatal encephalopathy, and acute radiation syndrome. The Orphan Regulation (Regulation (EC) No 141/2000) lays down the European Union procedure for the designation of orphan medicines; it defines the development and placing onto the market designated orphan medicines and establishes the Committee for Orphan Medicinal Products (COMP). Orphan products are still under investigation and are considered for orphan designation based on their potential activity. An orphan designation is not a marketing authorization. Therefore, it is necessary to demonstrate quality, safety, and efficacy before it can be granted a marketing authorization.

Depending on whether melatonin is treated as a drug (Directive 2001/83/EC) or as a dietary supplement (Regulation (EC) No 1924/2006), authorization and quality requirements differ significantly. The EU legal framework for human medicines guarantees higher standards of quality and safety. In other countries, such as the US or Canada, melatonin is an over-the-counter medication, up to a dose of $10 \mathrm{mg}$, without a prescription, and it is not regulated as strictly as other medicines. The FDA classifies melatonin as a dietary supplement; thus, there is no official FDA approval.

It is important to highlight that in the technical data of the UE-authorized melatonin drug, no severe adverse effects had been observed even at high doses ( $300 \mathrm{mg})$. Indeed, the incidence of adverse effects in treated patients is nearly the same as in the placebo group (EPAR for Circadin. Procedure No. EMEA/H/C/695). Based on this frame, the administration of low doses of melatonin may be effective for mild disorders such as insomnia, but when it comes to more severe diseases and in light of the previous doses administered in human clinical trials with effective results, it is likely that higher doses are needed.

\section{Conclusions}

Although melatonin does not have virucidal capacity per se, supplemental melatonin interceded favorably, eradicating the pathogenicity of highly deadly viruses $[16,19,227]$, as widely documented by numerous reports of different casuistry, among which the prevention of the hemorrhagic shock syndrome from Ebola virus infection is especially encouraging [17]. In this issue, taking into account the pharmacological profile of melatonin, which highlights formidable homeostatic abilities to moderate inflammation, mitigate redox stress, and buffer immune response, this indoleamine should occupy a preferential place among the molecules to be tested with regard to slowing down the hyper-inflammation of COVID-19 patients and increasing the success of their clinical management.

Over the last few months, immense efforts have been made to reposition existing drugs and alleviate the most threatening complications of the disease. So far, none of the explored possibilities have yielded widely favorable results; new possibilities continue to be investigated. Fortunately, the sudden development of dozens of vaccines, whose international distribution has recently begun, has been more successful. However, the recurrent appearance of genetic variants of SARS-CoV-2 raises the suspicion that the current pandemic will lead to future seasonal epidemic waves, in the style of those that occur every year. The need for palliative treatments against COVID-19 will not disappear despite the worldwide extension of vaccination campaigns, and therefore the importance of melatonin is not restricted to the control of the current pandemic but is projected to the clinical management of the disease in the future. However, a recent systematic review has reported twenty-four studies with slight adverse events attributed to melatonin (sleepiness, headache, or fatigue), while other more serious side effects were seen at very high doses or in specific populations [68]. In this context, some reports have evidenced that shortterm melatonin can sometimes lead to opposite effects to those expected, as a probable cause of diarrhea [228] or gynecomastia [229] or as a trigger of Crohn's disease [230]. Being a natural molecule, extensively studied, with high availability and tolerability, safe and low priced, the cost/benefit ratio is extremely advantageous for both purposes. 
It is therefore imperative to structure an international program of clinical trials, lowcost but with an immense potential benefit of historical dimensions. In a time in which vaccines are beginning to be distributed in many industrialized countries, some health international organizations denounce the gap of access in poor communities, claiming for a fair distribution of the unique measure that, in the medium- and long-term, can stop the ongoing challenge of the COVID-19 pandemic and save millions of lives. In this regard, we envisage that melatonin can be an immediate, effective, and global palliative. Therefore, in our opinion, the study of the clinical possibilities of supplemental melatonin in the management of COVID-19 is not simply another option to be tested, it is an ethical duty of translational research in clinical therapeutics. Our wish is that the current update of the possibilities of melatonin to impede SARS-CoV-2 morbimortality motivates immediate research programs that, as soon as possible, put into the hands of the clinicians a successful strategy for the clinical management of the health emergency of the COVID-19 pandemic that came by surprise into our lives just over a year ago.

Author Contributions: Conceptualization, methodology, writing original draft preparation, review and editing, supervision, and funding acquisition, A.R.; writing-review and editing, data curation, and tables, E.R.; review and editing, F.L.-M.; writing-original draft preparation, review and editing, data curation, and visualization, E.G.-M.; review and editing, J.E.; data curation, I.Á.-M.; review and editing and data curation, S.P.; review and editing and data curation, P.S.; conceptualization, writingoriginal draft preparation and review and editing, N.M.; conceptualization, writing-original draft preparation, review and editing, and supervision, J.M.H.-G. All authors have read and agreed to the published version of the manuscript.

Funding: A.R. is indebted to UCJC (NEWTHERMEL: UCJC 2019-02 and QUIMELTER: UCJC 2021-21) for financial support.

Conflicts of Interest: The authors declare no conflict of interest.

\section{References}

1. Chakraborty, I.; Maity, P. COVID-19 outbreak: Migration, effects on society, global environment and prevention. Sci. Total Environ. 2020, 728, 138882. [CrossRef] [PubMed]

2. Coronaviridae Study Group of the International Committee on Taxonomy of Viruses. The species Severe acute respiratory syndrome-related coronavirus: Classifying 2019-nCoV and naming it SARS-CoV-2. Nat. Microbiol. 2020, 5, 536-544. [CrossRef] [PubMed]

3. Slominski, A.; Fischer, T.W.; Zmijewski, M.A.; Wortsman, J.; Semak, I.; Zbytek, B.; Slominski, R.M.; Tobin, D.J. On the role of melatonin in skin physiology and pathology. Endocrine 2005, 27, 137-148. [CrossRef]

4. Tordjman, S.; Chokron, S.; Delorme, R.; Charrier, A.; Bellissant, E.; Jaafari, N.; Fougerou, C. Melatonin: Pharmacology, functions and therapeutic benefits. Curr. Neuropharmacol. 2017, 15, 434-443. [CrossRef]

5. Anisimov, V.N.; Popovich, I.G.; Zabezhinski, M.A.; Anisimov, S.V.; Vesnushkin, G.M.; Vinogradova, I.A. Melatonin as antioxidant, geroprotector and anticarcinogen. Biochim. Biophys. Acta 2006, 1757, 573-589. [CrossRef] [PubMed]

6. Chen, S.J.; Huang, S.H.; Chen, J.W.; Wang, K.C.; Yang, Y.R.; Liu, P.F.; Lin, G.J.; Sytwu, H.K. Melatonin enhances interleukin-10 expression and suppresses chemotaxis to inhibit inflammation in situ and reduce the severity of experimental autoimmune encephalomyelitis. Int. Immunopharmacol. 2016, 31, 169-177. [CrossRef]

7. Oxenkrug, G.; Requintina, P.; Bachurin, S. Antioxidant and antiaging activity of $N$-acetylserotonin and melatonin in the in vivo models. Ann. N. Y. Acad. Sci. 2006, 939, 190-199. [CrossRef]

8. Pandi-Perumal, S.R.; BaHammam, A.S.; Brown, G.M.; Spence, D.W.; Bharti, V.K.; Kaur, C.; Hardeland, R.; Cardinali, D.P. Melatonin antioxidative defense: Therapeutical implications for aging and neurodegenerative processes. Neurotox. Res. 2013, 23, 267-300. [CrossRef]

9. Arendt, J.; Skene, D.J. Melatonin as a chronobiotic. Sleep Med. Rev. 2005, 9, 25-39. [CrossRef]

10. Cardinali, D.P.; Brown, G.M.; Pandi-Perumal, S.R. Can melatonin be a potential "Silver Bullet" in treating COVID-19 patients? Diseases 2020, 8, 44. [CrossRef]

11. Reiter, R.J.; Abreu-Gonzalez, P.; Marik, P.E.; Dominguez-Rodriguez, A. Therapeutic algorithm for use of melatonin in patients with COVID-19. Front. Med. 2020, 7, 226. [CrossRef]

12. Hussman, J.P. Cellular and molecular pathways of COVID-19 and potential points of therapeutic intervention. Front. Pharmacol. 2020, 11, 1169. [CrossRef] [PubMed]

13. Luchetti, F.; Canonico, B.; Betti, M.; Arcangeletti, M.; Pilolli, F.; Piroddi, M.; Canesi, L.; Papa, S.; Galli, F. Melatonin signaling and cell protection function. FASEB J. 2010, 24, 3603-3624. [CrossRef] [PubMed] 
14. Cutando, A.; Lopez-Valverde, A.; Arias-Santiago, S.; De Vicente, J.; De Diego, R.G. Role of melatonin in cancer treatment. Anticancer Res. 2012, 32, 2747-2753. [PubMed]

15. Tay, M.Z.; Poh, C.M.; Renia, L.; MacAry, P.A.; Ng, L.F.P. The trinity of COVID-19: Immunity, inflammation and intervention. Nat. Rev. Immunol. 2020, 20, 363-374. [CrossRef] [PubMed]

16. Bonilla, E.; Valero, N.; Chacin-Bonilla, L.; Medina-Leendertz, S. Melatonin and viral infections. J. Pineal Res. 2004, 36, 73-79. [CrossRef]

17. Reiter, R.; Ma, Q.; Sharma, R. Treatment of ebola and other infectious diseases: Melatonin "goes viral". Melatonin Res. 2020, 3, 43-57. [CrossRef]

18. Tan, D.-X.; Hardeland, R. Potential utility of melatonin in deadly infectious diseases related to the overreaction of innate immune response and destructive inflammation: Focus on COVID-19. Melatonin Res. 2020, 3, 120-143. [CrossRef]

19. Juybari, K.B.; Pourhanifeh, M.H.; Hosseinzadeh, A.; Hemati, K.; Mehrzadi, S. Melatonin potentials against viral infections including COVID-19: Current evidence and new findings. Virus Res. 2020, 287, 198108. [CrossRef]

20. Crespi, B. Evolutionary medical insights into the SARS-CoV-2 pandemic. Evol. Med. Public Health 2020, 2020, 314-322. [CrossRef] [PubMed]

21. Karasek, M. Melatonin, human aging, and age-related diseases. Exp. Gerontol. 2004, 39, 1723-1729. [CrossRef]

22. Waldhauser, F.; Weiszenbacher, G.; Frisch, H.; Zeitlhuber, U.; Waldhauser, M.; Wurtman, R.J. Fall in nocturnal serum melatonin during prepuberty and pubescence. Lancet 1984, 323, 362-365. [CrossRef]

23. Shneider, A.; Kudriavtsev, A.; Vakhrusheva, A. Can melatonin reduce the severity of COVID-19 pandemic? Int. Rev. Immunol. 2020, 39, 153-162. [CrossRef]

24. Zhou, Y.; Hou, Y.; Shen, J.; Huang, Y.; Martin, W.; Cheng, F. Network-based drug repurposing for novel coronavirus 2019nCoV/SARS-CoV-2. Cell Discov. 2020, 6, 14. [CrossRef] [PubMed]

25. Zhou, Y.; Hou, Y.; Shen, J.; Kallianpur, A.; Zein, J.; Culver, D.A.; Farha, S.; Comhair, S.; Fiocchi, C.; Gack, M.U.; et al. A network medicine approach to investigation and population-based validation of disease manifestations and drug repurposing for COVID-19. ChemRxiv 2020. [CrossRef]

26. Al-Zaqri, N.; Pooventhiran, T.; Alsalme, A.; Warad, I.; John, A.M.; Thomas, R. Structural and physico-chemical evaluation of melatonin and its solution-state excited properties, with emphasis on its binding with novel coronavirus proteins. J. Mol. Liq. 2020, 318, 114082. [CrossRef] [PubMed]

27. Feitosa, E.L.; Junior, F.; Neto, J.A.O.N.; Matos, L.F.L.; Moura, M.H.S.; Rosales, T.O.; De Freitas, G.B.L. COVID-19: Rational discovery of the therapeutic potential of melatonin as a SARS-CoV-2 main protease inhibitor. Int. J. Med. Sci. 2020, 17, 2133-2146. [CrossRef] [PubMed]

28. Jehi, L.; Ji, X.; Milinovich, A.; Erzurum, S.; Rubin, B.P.; Gordon, S.; Young, J.B.; Kattan, M.W. Individualizing risk prediction for positive coronavirus disease 2019 testing: Results from 11,672 patients. Chest 2020, 158, 1364-1375. [CrossRef]

29. Kleszczynski, K.; Slominski, A.T.; Steinbrink, K.; Reiter, R.J. Clinical trials for use of melatonin to fight against COVID-19 are urgently needed. Nutrients 2020, 12, 2561. [CrossRef] [PubMed]

30. Maestroni, G. Exogenous melatonin as potential adjuvant in anti-SarsCov2 vaccines. J. Neuroimmune Pharmacol. 2020, 15, 572-573. [CrossRef]

31. Zhang, R.; Wang, X.; Ni, L.; Di, X.; Ma, B.; Niu, S.; Liu, C.; Reiter, R.J. COVID-19: Melatonin as a potential adjuvant treatment. Life Sci. 2020, 250, 117583. [CrossRef] [PubMed]

32. Cardinali, D.; Brown, G.; Pandi-Perumal, S. An urgent proposal for the immediate use of melatonin as an adjuvant to anti-SARSCoV-2 vaccination. Melatonin Res. 2021, 4, 206-212. [CrossRef]

33. Hu, B.; Huang, S.; Yin, L. The cytokine storm and COVID-19. J. Med. Virol. 2021, 93, 250-256. [CrossRef] [PubMed]

34. Song, P.; Li, W.; Xie, J.; Hou, Y.; You, C. Cytokine storm induced by SARS-CoV-2. Clin. Chim. Acta 2020, 509, 280-287. [CrossRef]

35. Wang, C.; Xie, J.; Zhao, L.; Fei, X.; Zhang, H.; Tan, Y.; Nie, X.; Zhou, L.; Liu, Z.; Ren, Y.; et al. Alveolar macrophage dysfunction and cytokine storm in the pathogenesis of two severe COVID-19 patients. EBioMedicine 2020, 57, 102833. [CrossRef]

36. Mokhtari, T.; Hassani, F.; Ghaffari, N.; Ebrahimi, B.; Yarahmadi, A.; Hassanzadeh, G. COVID-19 and multiorgan failure: A narrative review on potential mechanisms. J. Mol. Histol. 2020, 51, 613-628. [CrossRef]

37. Huang, C.; Wang, Y.; Li, X.; Ren, L.; Zhao, J.; Hu, Y.; Zhang, L.; Fan, G.; Xu, J.; Gu, X.; et al. Clinical features of patients infected with 2019 novel coronavirus in Wuhan, China. Lancet 2020, 395, 497-506. [CrossRef]

38. Boga, J.A.; Coto-Montes, A.; Rosales-Corral, S.A.; Tan, D.X.; Reiter, R.J. Beneficial actions of melatonin in the management of viral infections: A new use for this "molecular handyman"? Rev. Med. Virol. 2012, 22, 323-338. [CrossRef]

39. Valero, N.; Mosquera, J.; Alcocer, S.; Bonilla, E.; Salazar, J.; Alvarez-Mon, M. Melatonin, minocycline and ascorbic acid reduce oxidative stress and viral titers and increase survival rate in experimental Venezuelan equine encephalitis. Brain Res. 2015, 1622, 368-376. [CrossRef]

40. Huang, S.-H.; Liao, C.-L.; Chen, S.-J.; Shi, L.-G.; Lin, L.; Chen, Y.-W.; Cheng, C.-P.; Sytwu, H.-K.; Shang, S.-T.; Lin, G.-J. Melatonin possesses an anti-influenza potential through its immune modulatory effect. J. Funct. Foods 2019, 58, 189-198. [CrossRef]

41. Jacob, S.; Poeggeler, B.; Weishaupt, J.H.; Siren, A.L.; Hardeland, R.; Bahr, M.; Ehrenreich, H. Melatonin as a candidate compound for neuroprotection in amyotrophic lateral sclerosis (ALS): High tolerability of daily oral melatonin administration in ALS patients. J. Pineal Res. 2002, 33, 186-187. [CrossRef] 
42. Andersen, L.P.; Werner, M.U.; Rosenkilde, M.M.; Fenger, A.Q.; Petersen, M.C.; Rosenberg, J.; Gogenur, I. Pharmacokinetics of high-dose intravenous melatonin in humans. J. Clin. Pharmacol. 2016, 56, 324-329. [CrossRef]

43. Cunha, L.L.; Perazzio, S.F.; Azzi, J.; Cravedi, P.; Riella, L.V. Remodeling of the immune response with aging: Immunosenescence and its potential impact on COVID-19 immune response. Front. Immunol. 2020, 11, 1748. [CrossRef]

44. Vabret, N.; Britton, G.J.; Gruber, C.; Hegde, S.; Kim, J.; Kuksin, M.; Levantovsky, R.; Malle, L.; Moreira, A.; Park, M.D.; et al. Immunology of COVID-19: Current state of the science. Immunity 2020, 52, 910-941. [CrossRef] [PubMed]

45. Nunn, A.V.W.; Guy, G.W.; Brysch, W.; Botchway, S.W.; Frasch, W.; Calabrese, E.J.; Bell, J.D. SARS-CoV-2 and mitochondrial health: Implications of lifestyle and ageing. Immun. Ageing 2020, 17, 33. [CrossRef] [PubMed]

46. Friedman, M. Analysis, nutrition, and health benefits of tryptophan. Int. J. Tryptophan Res. 2018, 11, 1178646918802282. [CrossRef] [PubMed]

47. Rahman, M.M.; Talukder, A.; Chowdhury, M.M.H.; Talukder, R.; Akter, R. Coronaviruses in wild birds-A potential and suitable vector for global distribution. Vet. Med. Sci. 2021, 7, 264-272. [CrossRef] [PubMed]

48. Lu, R.; Zhao, X.; Li, J.; Niu, P.; Yang, B.; Wu, H.; Wang, W.; Song, H.; Huang, B.; Zhu, N.; et al. Genomic characterisation and epidemiology of 2019 novel coronavirus: Implications for virus origins and receptor binding. Lancet 2020, 395, 565-574. [CrossRef]

49. Licastro, D.; Rajasekharan, S.; Monego, S.D.; Segat, L.; D'Agaro, P.; Marcello, A. Isolation and full-length genome characterization of SARS-CoV-2 from COVID-19 cases in Northern Italy. J. Virol. 2020, 94, e00543-20. [CrossRef]

50. Wu, A.; Peng, Y.; Huang, B.; Ding, X.; Wang, X.; Niu, P.; Meng, J.; Zhu, Z.; Zhang, Z.; Wang, J.; et al. Genome composition and divergence of the Novel Coronavirus (2019-nCoV) originating in China. Cell Host Microbe 2020, 27, 325-328. [CrossRef]

51. Chan, J.F.; Kok, K.H.; Zhu, Z.; Chu, H.; To, K.K.; Yuan, S.; Yuen, K.Y. Genomic characterization of the 2019 novel humanpathogenic coronavirus isolated from a patient with atypical pneumonia after visiting Wuhan. Emerg. Microbes Infect. 2020, 9 , 221-236. [CrossRef]

52. Lefkowitz, E.J.; Dempsey, D.M.; Hendrickson, R.C.; Orton, R.J.; Siddell, S.G.; Smith, D.B. Virus taxonomy: The database of the International Committee on Taxonomy of Viruses (ICTV). Nucleic Acids Res. 2018, 46, D708-D717. [CrossRef]

53. Simmons, G.; Gosalia, D.N.; Rennekamp, A.J.; Reeves, J.D.; Diamond, S.L.; Bates, P. Inhibitors of cathepsin L prevent severe acute respiratory syndrome coronavirus entry. Proc. Natl. Acad. Sci. USA 2005, 102, 11876-11881. [CrossRef]

54. Hu, B.; Guo, H.; Zhou, P.; Shi, Z.L. Characteristics of SARS-CoV-2 and COVID-19. Nat. Rev. Microbiol. 2021, 19, 141-154. [CrossRef]

55. Li, F. Structure, function, and evolution of coronavirus spike proteins. Annu. Rev. Virol. 2016, 3, 237-261. [CrossRef]

56. Li, W.; Moore, M.J.; Vasilieva, N.; Sui, J.; Wong, S.K.; Berne, M.A.; Somasundaran, M.; Sullivan, J.L.; Luzuriaga, K.; Greenough, T.C.; et al. Angiotensin-converting enzyme 2 is a functional receptor for the SARS coronavirus. Nature 2003, 426, 450-454. [CrossRef] [PubMed]

57. Zhou, F.; Yu, T.; Du, R.; Fan, G.; Liu, Y.; Liu, Z.; Xiang, J.; Wang, Y.; Song, B.; Gu, X.; et al. Clinical course and risk factors for mortality of adult inpatients with COVID-19 in Wuhan, China: A retrospective cohort study. Lancet 2020, 395, 1054-1062. [CrossRef]

58. Donoghue, M.; Hsieh, F.; Baronas, E.; Godbout, K.; Gosselin, M.; Stagliano, N.; Donovan, M.; Woolf, B.; Robison, K.; Jeyaseelan, R.; et al. A novel angiotensin-converting enzyme-related carboxypeptidase (ACE2) converts angiotensin I to angiotensin 1-9. Circ. Res. 2000, 87, e1-e9. [CrossRef]

59. Zou, X.; Chen, K.; Zou, J.; Han, P.; Hao, J.; Han, Z. Single-cell RNA-seq data analysis on the receptor ACE2 expression reveals the potential risk of different human organs vulnerable to 2019-nCoV infection. Front. Med. 2020, 14, 185-192. [CrossRef] [PubMed]

60. Xiao, F.; Tang, M.; Zheng, X.; Liu, Y.; Li, X.; Shan, H. Evidence for gastrointestinal infection of SARS-CoV-2. Gastroenterology 2020, 158, 1831-1833. [CrossRef] [PubMed]

61. Cheng, Y.; Luo, R.; Wang, K.; Zhang, M.; Wang, Z.; Dong, L.; Li, J.; Yao, Y.; Ge, S.; Xu, G. Kidney disease is associated with in-hospital death of patients with COVID-19. Kidney Int. 2020, 97, 829-838. [CrossRef]

62. Guan, G.W.; Gao, L.; Wang, J.W.; Wen, X.J.; Mao, T.H.; Peng, S.W.; Zhang, T.; Chen, X.M.; Lu, F.M. Exploring the mechanism of liver enzyme abnormalities in patients with novel coronavirus-infected pneumonia. Zhonghua Gan Zang Bing Za Zhi 2020, 28, 100-106. [CrossRef]

63. Menni, C.; Sudre, C.H.; Steves, C.J.; Ourselin, S.; Spector, T.D. Quantifying additional COVID-19 symptoms will save lives. Lancet 2020, 395, e107-e108. [CrossRef]

64. Wang, B.; Li, R.; Lu, Z.; Huang, Y. Does comorbidity increase the risk of patients with COVID-19: Evidence from meta-analysis. Aging 2020, 12, 6049-6057. [CrossRef] [PubMed]

65. Van Doremalen, N.; Bushmaker, T.; Morris, D.H.; Holbrook, M.G.; Gamble, A.; Williamson, B.N.; Tamin, A.; Harcourt, J.L.; Thornburg, N.J.; Gerber, S.I.; et al. Aerosol and surface stability of SARS-CoV-2 as compared with SARS-CoV-1. N. Engl. J. Med. 2020, 382, 1564-1567. [CrossRef] [PubMed]

66. Reiter, R.J. Oxidative processes and antioxidative defense mechanisms in the aging brain. FASEB J. 1995, 9, 526-533. [CrossRef] [PubMed]

67. Ferlazzo, N.; Andolina, G.; Cannata, A.; Costanzo, M.G.; Rizzo, V.; Curro, M.; Ientile, R.; Caccamo, D. Is melatonin the cornucopia of the 21st century? Antioxidants 2020, 9, 1088. [CrossRef] [PubMed]

68. Foley, H.M.; Steel, A.E. Adverse events associated with oral administration of melatonin: A critical systematic review of clinical evidence. Complement. Ther. Med. 2019, 42, 65-81. [CrossRef] [PubMed] 
69. Sanchez-Barcelo, E.J.; Mediavilla, M.D.; Tan, D.X.; Reiter, R.J. Clinical uses of melatonin: Evaluation of human trials. Curr. Med. Chem. 2010, 17, 2070-2095. [CrossRef]

70. Li, T.; Jiang, S.; Han, M.; Yang, Z.; Lv, J.; Deng, C.; Reiter, R.J.; Yang, Y. Exogenous melatonin as a treatment for secondary sleep disorders: A systematic review and meta-analysis. Front. Neuroendocr. 2019, 52, 22-28. [CrossRef]

71. Akbari, M.; Ostadmohammadi, V.; Tabrizi, R.; Lankarani, K.B.; Heydari, S.T.; Amirani, E.; Reiter, R.J.; Asemi, Z. The effects of melatonin supplementation on inflammatory markers among patients with metabolic syndrome or related disorders: A systematic review and meta-analysis of randomized controlled trials. Inflammopharmacology 2018, 26, 899-907. [CrossRef]

72. Li, Y.; Li, S.; Zhou, Y.; Meng, X.; Zhang, J.J.; Xu, D.P.; Li, H.B. Melatonin for the prevention and treatment of cancer. Oncotarget 2017, 8, 39896-39921. [CrossRef] [PubMed]

73. Kubatka, P.; Zubor, P.; Busselberg, D.; Kwon, T.K.; Adamek, M.; Petrovic, D.; Opatrilova, R.; Gazdikova, K.; Caprnda, M.; Rodrigo, L.; et al. Melatonin and breast cancer: Evidences from preclinical and human studies. Crit. Rev. Oncol. Hematol. 2018, 122, 133-143. [CrossRef] [PubMed]

74. Pourhanifeh, M.H.; Mehrzadi, S.; Kamali, M.; Hosseinzadeh, A. Melatonin and gastrointestinal cancers: Current evidence based on underlying signaling pathways. Eur. J. Pharmacol. 2020, 886, 173471. [CrossRef] [PubMed]

75. Capote-Moreno, A.; Ramos, E.; Egea, J.; Lopez-Munoz, F.; Gil-Martin, E.; Romero, A. Potential of melatonin as adjuvant therapy of oral cancer in the era of epigenomics. Cancers 2019, 11, 1712. [CrossRef]

76. Gil-Martin, E.; Egea, J.; Reiter, R.J.; Romero, A. The emergence of melatonin in oncology: Focus on colorectal cancer. Med. Res. Rev. 2019, 39, 2239-2285. [CrossRef]

77. Anderson, G.; Reiter, R.J. Melatonin: Roles in influenza, Covid-19, and other viral infections. Rev. Med. Virol. 2020, 30, e2109. [CrossRef] [PubMed]

78. Wongchitrat, P.; Shukla, M.; Sharma, R.; Govitrapong, P.; Reiter, R.J. Role of melatonin on virus-induced neuropathogenesis-A concomitant therapeutic strategy to understand SARS-CoV-2 infection. Antioxidants 2021, 10, 47. [CrossRef]

79. Romero, A.; Ramos, E.; Lopez-Munoz, F.; Gil-Martin, E.; Escames, G.; Reiter, R.J. Coronavirus disease 2019 (COVID-19) and its neuroinvasive capacity: Is it time for melatonin? Cell. Mol. Neurobiol. 2020. [CrossRef]

80. Garcia, I.G.; Rodriguez-Rubio, M.; Mariblanca, A.R.; de Soto, L.M.; Garcia, L.D.; Villatoro, J.M.; Parada, J.Q.; Meseguer, E.S.; Rosales, M.J.; Gonzalez, J.; et al. A randomized multicenter clinical trial to evaluate the efficacy of melatonin in the prophylaxis of SARS-CoV-2 infection in high-risk contacts (MeCOVID Trial): A structured summary of a study protocol for a randomised controlled trial. Trials 2020, 21, 466. [CrossRef]

81. Rodriguez-Rubio, M.; Figueira, J.C.; Acuna-Castroviejo, D.; Borobia, A.M.; Escames, G.; de la Oliva, P. A phase II, single-center double-blind, randomized placebo-controlled trial to explore the efficacy and safety of intravenous melatonin in patients with COVID-19 admitted to the intensive care unit (MelCOVID study): A structured summary of a study protocol for a randomized controlled trial. Trials 2020, 21, 699. [CrossRef]

82. Acuna-Castroviejo, D.; Escames, G.; Figueira, J.C.; de la Oliva, P.; Borobia, A.M.; Acuna-Fernandez, C. Clinical trial to test the efficacy of melatonin in COVID-19. J. Pineal Res. 2020, 69, e12683. [CrossRef] [PubMed]

83. Ziaei, A.; Davoodian, P.; Dadvand, H.; Safa, O.; Hassanipour, S.; Omidi, M.; Masjedi, M.; Mahmoudikia, F.; Rafiee, B.; Fathalipour, M. Evaluation of the efficacy and safety of Melatonin in moderately ill patients with COVID-19: A structured summary of a study protocol for a randomized controlled trial. Trials 2020, 21, 882. [CrossRef] [PubMed]

84. Ramos, E.; Farre-Alins, V.; Egea, J.; Lopez-Munoz, F.; Reiter, R.J.; Romero, A. Melatonin's efficacy in stroke patients; a matter of dose? A systematic review. Toxicol. Appl. Pharmacol. 2020, 392, 114933. [CrossRef]

85. Stevens, R.G. Light-at-night, circadian disruption and breast cancer: Assessment of existing evidence. Int. J. Epidemiol. 2009, 38, 963-970. [CrossRef] [PubMed]

86. Reiter, R.J. Melatonin: Clinical relevance. Best Pract. Res. Clin. Endocrinol. Metab. 2003, 17, 273-285. [CrossRef]

87. Cardinali, D.P.; Brown, G.M.; Reiter, R.J.; Pandi-Perumal, S.R. Elderly as a high-risk group during COVID-19 pandemic: Effect of circadian misalignment, sleep dysregulation and melatonin administration. Sleep Vigil. 2020, 4, 81-87. [CrossRef]

88. Golan, K.; Kollet, O.; Markus, R.P.; Lapidot, T. Daily light and darkness onset and circadian rhythms metabolically synchronize hematopoietic stem cell differentiation and maintenance: The role of bone marrow norepinephrine, tumor necrosis factor, and melatonin cycles. Exp. Hematol. 2019, 78, 1-10. [CrossRef]

89. Huang, H.W.; Zheng, B.L.; Jiang, L.; Lin, Z.T.; Zhang, G.B.; Shen, L.; Xi, X.M. Effect of oral melatonin and wearing earplugs and eye masks on nocturnal sleep in healthy subjects in a simulated intensive care unit environment: Which might be a more promising strategy for ICU sleep deprivation? Crit. Care 2015, 19, 124. [CrossRef]

90. Ahmed, M. Avoiding room light during night may stimulate immunity in COVID-19 patients by promoting melatonin production. Melatonin Res. 2020, 3, 476-481. [CrossRef]

91. Lim, R.K.; Wambier, C.G.; Goren, A. Are night shift workers at an increased risk for COVID-19? Med. Hypotheses 2020, 144, 110147. [CrossRef]

92. Palagini, L.; Manni, R.; Aguglia, E.; Amore, M.; Brugnoli, R.; Girardi, P.; Grassi, L.; Mencacci, C.; Plazzi, G.; Minervino, A.; et al. Evaluation and management of insomnia in clinical practice and in the time of COVID-19 in Italy: Expert consensus and task-force recommendations from five scientific societies. Riv. Psichiatr. 2020, 55, 337-341. [CrossRef]

93. Mao, L.; Jin, H.; Wang, M.; Hu, Y.; Chen, S.; He, Q.; Chang, J.; Hong, C.; Zhou, Y.; Wang, D.; et al. Neurologic manifestations of hospitalized patients with coronavirus disease 2019 in Wuhan, China. JAMA Neurol. 2020, 77, 683-690. [CrossRef] 
94. Zambrelli, E.; Canevini, M.; Gambini, O.; D’Agostino, A. Delirium and sleep disturbances in COVID-19: A possible role for melatonin in hospitalized patients? Sleep Med. 2020, 70, 111. [CrossRef]

95. Sher, Y.; Rabkin, B.; Maldonado, J.R.; Mohabir, P. COVID-19-Associated hyperactive intensive care unit delirium with proposed pathophysiology and treatment: A case report. Psychosomatics 2020, 61, 544-550. [CrossRef]

96. Richardson, S.; Hirsch, J.S.; Narasimhan, M.; Crawford, J.M.; McGinn, T.; Davidson, K.W.; the Northwell, C.-R.C.; Barnaby, D.P.; Becker, L.B.; Chelico, J.D.; et al. Presenting characteristics, comorbidities, and outcomes among 5700 patients hospitalized with COVID-19 in the New York City Area. JAMA 2020, 323, 2052-2059. [CrossRef]

97. Karamitri, A.; Jockers, R. Melatonin in type 2 diabetes mellitus and obesity. Nat. Rev. Endocrinol. 2019, 15, 105-125. [CrossRef]

98. Barone, M.T.U.; Ngongo, B.; Menna-Barreto, L. Sleep-wake cycle impairment adding on the risk for COVID-19 severity in people with diabetes. Sleep Sci. 2020, 13, 191-194. [CrossRef] [PubMed]

99. Miller, M.A.; Cappuccio, F.P. A systematic review of COVID-19 and obstructive sleep apnoea. Sleep Med. Rev. 2021, 55, 101382. [CrossRef] [PubMed]

100. Brown, G.M.; Karthikeyan, R.; Pandi-Perumal, S.R.; Cardinali, D.P. Autism spectrum disorder patients may be susceptible to COVID-19 disease due to deficiency in melatonin. Med. Hypotheses 2021, 149, 110544. [CrossRef] [PubMed]

101. Ulrich, H.; Pillat, M.M. CD147 as a target for COVID-19 treatment: Suggested effects of azithromycin and stem cell engagement. Stem Cell Rev. Rep. 2020, 16, 434-440. [CrossRef]

102. Loh, D. The potential of melatonin in the prevention and attenuation of oxidative hemolysis and myocardial injury from cd147 SARS-CoV-2 spike protein receptor binding. Melatonin Res. 2020, 3, 380-416. [CrossRef]

103. Su, H.; Li, J.; Chen, T.; Li, N.; Xiao, J.; Wang, S.; Guo, X.; Yang, Y.; Bu, P. Melatonin attenuates angiotensin II-induced cardiomyocyte hypertrophy through the CyPA/CD147 signaling pathway. Mol. Cell. Biochem. 2016, 422, 85-95. [CrossRef] [PubMed]

104. Sehirli, A.O.; Sayiner, S.; Serakinci, N. Role of melatonin in the treatment of COVID-19; as an adjuvant through cluster differentiation 147 (CD147). Mol. Biol. Rep. 2020, 47, 8229-8233. [CrossRef] [PubMed]

105. Wang, Y.; Han, D.; Zhou, T.; Zhang, J.; Liu, C.; Cao, F.; Dong, N. Melatonin ameliorates aortic valve calcification via the regulation of circular RNA CircRIC3/miR-204-5p/DPP4 signaling in valvular interstitial cells. J. Pineal Res. 2020, 69, e12666. [CrossRef] [PubMed]

106. Anderson, G.; Carbone, A.; Mazzoccoli, G. Aryl hydrocarbon receptor role in co-ordinating sars-cov-2 entry and symptomatology: Linking cytotoxicity changes in COVID-19 and cancers; modulation by racial discrimination stress. Biology 2020, 9, 249. [CrossRef]

107. Grunewald, M.E.; Shaban, M.G.; Mackin, S.R.; Fehr, A.R.; Perlman, S. Murine coronavirus infection activates the aryl hydrocarbon receptor in an indoleamine 2,3-dioxygenase-independent manner, contributing to cytokine modulation and proviral TCDDinducible-PARP expression. J. Virol. 2020, 94. [CrossRef] [PubMed]

108. Zuo, T.; Zhang, F.; Lui, G.C.Y.; Yeoh, Y.K.; Li, A.Y.L.; Zhan, H.; Wan, Y.; Chung, A.C.K.; Cheung, C.P.; Chen, N.; et al. Alterations in gut microbiota of patients with COVID-19 during time of hospitalization. Gastroenterology 2020, 159, 944-955.e8. [CrossRef]

109. Anderson, G.; Rodriguez, M.; Reiter, R.J. Multiple sclerosis: Melatonin, orexin, and ceramide interact with platelet activation coagulation factors and gut-microbiome-derived butyrate in the circadian dysregulation of mitochondria in glia and immune cells. Int. J. Mol. Sci. 2019, 20, 5500. [CrossRef]

110. Anderson, G.; Carbone, A.; Mazzoccoli, G. Tryptophan metabolites and aryl hydrocarbon receptor in severe acute respiratory syndrome, Coronavirus-2 (SARS-CoV-2) pathophysiology. Int. J. Mol. Sci. 2021, 22, 1597. [CrossRef]

111. Cheng, F.; Rao, S.; Mehra, R. COVID-19 treatment: Combining anti-inflammatory and antiviral therapeutics using a network-based approach. Clevel. Clin. J. Med. 2020. [CrossRef]

112. Parlakpinar, H.; Polat, S.; Acet, H.A. Pharmacological agents under investigation in the treatment of coronavirus disease 2019 and the importance of melatonin. Fundam. Clin. Pharmacol. 2021, 35, 62-75. [CrossRef] [PubMed]

113. Ramlall, V.; Zucker, J.; Tatonetti, N. Melatonin is significantly associated with survival of intubated COVID-19 patients. medRxiv 2020. [CrossRef]

114. Maruta, H.; He, H. PAK1-blockers: Potential therapeutics against COVID-19. Med. Drug Discov. 2020, 6, 100039. [CrossRef] [PubMed]

115. Klann, K.; Bojkova, D.; Tascher, G.; Ciesek, S.; Munch, C.; Cinatl, J. Growth factor receptor signaling inhibition prevents SARS-CoV-2 replication. Mol. Cell 2020, 80, 164-174.e164. [CrossRef]

116. Tesarik, J. Melatonin attenuates growth factor receptor signaling required for SARS-CoV-2 replication. Melatonin Res. 2020, 3 , 534-537. [CrossRef]

117. Bansal, R.; Gubbi, S.; Muniyappa, R. Metabolic syndrome and COVID 19: Endocrine-immune-vascular interactions shapes clinical course. Endocrinology 2020, 161, bqaa112. [CrossRef] [PubMed]

118. Barek, M.A.; Aziz, M.A.; Islam, M.S. Impact of age, sex, comorbidities and clinical symptoms on the severity of COVID-19 cases: A meta-analysis with 55 studies and 10014 cases. Heliyon 2020, 6, e05684. [CrossRef]

119. Biswas, M.; Rahaman, S.; Biswas, T.K.; Haque, Z.; Ibrahim, B. Association of sex, age, and comorbidities with mortality in covid-19 patients: A systematic review and meta-analysis. Intervirology 2020, 64, 36-47. [CrossRef]

120. Mauvais-Jarvis, F. Aging, male sex, obesity, and metabolic inflammation create the perfect storm for COVID-19. Diabetes 2020, 69, 1857-1863. [CrossRef]

121. Yang, J.; Zheng, Y.; Gou, X.; Pu, K.; Chen, Z.; Guo, Q.; Ji, R.; Wang, H.; Wang, Y.; Zhou, Y. Prevalence of comorbidities and its effects in patients infected with SARS-CoV-2: A systematic review and meta-analysis. Int. J. Infect. Dis. 2020, 94, 91-95. [CrossRef] 
122. Stokes, E.K.; Zambrano, L.D.; Anderson, K.N.; Marder, E.P.; Raz, K.M.; Felix, S.E.B.; Tie, Y.; Fullerton, K.E. Coronavirus disease 2019 case surveillance-United States, 22 January-30 May 2020. Morb. Mortal. Wkly. Rep. 2020, 69, 759-765. [CrossRef] [PubMed]

123. Team, C.C.-R. Preliminary estimates of the prevalence of selected underlying health conditions among patients with Coronavirus Disease 2019-United States, February 12-March 28, 2020. Morb. Mortal. Wkly. Rep. 2020, 69, 382-386. [CrossRef]

124. Ng, W.H.; Tipih, T.; Makoah, N.A.; Vermeulen, J.G.; Goedhals, D.; Sempa, J.B.; Burt, F.J.; Taylor, A.; Mahalingam, S. Comorbidities in SARS-CoV-2 patients: A systematic review and meta-analysis. mBio 2021, 12, e03647-20. [CrossRef] [PubMed]

125. Wang, A.; Luan, H.H.; Medzhitov, R. An evolutionary perspective on immunometabolism. Science 2019, 363. [CrossRef]

126. Esser, N.; Paquot, N.; Scheen, A.J. Inflammatory markers and cardiometabolic diseases. Acta Clin. Belg. 2015, 70, 193-199. [CrossRef]

127. Lumeng, C.N.; Bodzin, J.L.; Saltiel, A.R. Obesity induces a phenotypic switch in adipose tissue macrophage polarization. J. Clin. Investig. 2007, 117, 175-184. [CrossRef]

128. Makowski, L.; Chaib, M.; Rathmell, J.C. Immunometabolism: From basic mechanisms to translation. Immunol. Rev. 2020, 295, 5-14. [CrossRef]

129. Hotamisligil, G.S. Inflammation and metabolic disorders. Nature 2006, 444, 860-867. [CrossRef]

130. Batabyal, R.; Freishtat, N.; Hill, E.; Rehman, M.; Freishtat, R.; Koutroulis, I. Metabolic dysfunction and immunometabolism in COVID-19 pathophysiology and therapeutics. Int. J. Obes. 2021, 45, 1163-1169. [CrossRef]

131. Cardinali, D.P.; Vigo, D.E. Melatonin, mitochondria, and the metabolic syndrome. Cell. Mol. Life Sci. 2017, 74, 3941-3954. [CrossRef] [PubMed]

132. Mehrzadi, S.; Karimi, M.Y.; Fatemi, A.; Reiter, R.J.; Hosseinzadeh, A. SARS-CoV-2 and other coronaviruses negatively influence mitochondrial quality control: Beneficial effects of melatonin. Pharmacol. Ther. 2021, 224, 107825. [CrossRef] [PubMed]

133. Hardeland, R. Melatonin in aging and disease -multiple consequences of reduced secretion, options and limits of treatment. Aging Dis. 2012, 3, 194-225.

134. Cardinali, D.P.; Hardeland, R. Inflammaging, metabolic syndrome and melatonin: A call for treatment studies. Neuroendocrinology 2017, 104, 382-397. [CrossRef]

135. Cardinali, D. High doses of melatonin as a potential therapeutic tool for the neurologic sequels of covid-19 infection. Melatonin Res. 2020, 3, 311-317. [CrossRef]

136. Imenshahidi, M.; Karimi, G.; Hosseinzadeh, H. Effects of melatonin on cardiovascular risk factors and metabolic syndrome: A comprehensive review. Naunyn Schmiedebergs Arch. Pharmacol. 2020, 393, 521-536. [CrossRef]

137. Acuna-Castroviejo, D.; Carretero, M.; Doerrier, C.; Lopez, L.C.; Garcia-Corzo, L.; Tresguerres, J.A.; Escames, G. Melatonin protects lung mitochondria from aging. Age 2012, 34, 681-692. [CrossRef]

138. Brum, M.C.; Filho, F.F.; Schnorr, C.C.; Bottega, G.B.; Rodrigues, T.C. Shift work and its association with metabolic disorders. Diabetol. Metab. Syndr. 2015, 7, 45. [CrossRef]

139. Kulkarni, K.; Schow, M.; Shubrook, J.H. Shift workers at risk for metabolic syndrome. J. Am. Osteopath. Assoc. 2020, 120, 107-117. [CrossRef]

140. Carrillo-Vico, A.; Lardone, P.J.; Alvarez-Sanchez, N.; Rodriguez-Rodriguez, A.; Guerrero, J.M. Melatonin: Buffering the immune system. Int. J. Mol. Sci. 2013, 14, 8638-8683. [CrossRef]

141. El-Missiry, M.A.; El-Missiry, Z.M.A.; Othman, A.I. Melatonin is a potential adjuvant to improve clinical outcomes in individuals with obesity and diabetes with coexistence of Covid-19. Eur. J. Pharmacol. 2020, 882, 173329. [CrossRef]

142. Mazzoccoli, G.; Kvetnoy, I.; Mironova, E.; Yablonskiy, P.; Sokolovich, E.; Krylova, J.; Carbone, A.; Anderson, G.; Polyakova, V. The melatonergic pathway and its interactions in modulating respiratory system disorders. Biomed. Pharmacother. 2021, 137, 111397. [CrossRef]

143. Tan, D.X.; Manchester, L.C.; Qin, L.; Reiter, R.J. Melatonin: A mitochondrial targeting molecule involving mitochondrial protection and dynamics. Int. J. Mol. Sci. 2016, 17, 2124. [CrossRef] [PubMed]

144. Reiter, R.J.; Rosales-Corral, S.; Tan, D.X.; Jou, M.J.; Galano, A.; Xu, B. Melatonin as a mitochondria-targeted antioxidant: One of evolution's best ideas. Cell. Mol. Life Sci. 2017, 74, 3863-3881. [CrossRef]

145. Polyakova, V.O.; Kvetnoy, I.M.; Anderson, G.; Rosati, J.; Mazzoccoli, G.; Linkova, N.S. Reciprocal interactions of mitochondria and the neuroimmunoendocrine system in neurodegenerative disorders: An important role for melatonin regulation. Front. Physiol. 2018, 9, 199. [CrossRef] [PubMed]

146. Reiter, R.J.; Sharma, R.; Ma, Q.; Dominquez-Rodriguez, A.; Marik, P.E.; Abreu-Gonzalez, P. Melatonin inhibits COVID-19-induced cytokine storm by reversing aerobic glycolysis in immune cells: A mechanistic analysis. Med. Drug Discov. 2020, 6, 100044. [CrossRef]

147. Owino, S.; Buonfiglio, D.D.C.; Tchio, C.; Tosini, G. Melatonin signaling a key regulator of glucose homeostasis and energy metabolism. Front. Endocrinol. 2019, 10, 488. [CrossRef] [PubMed]

148. Shatilo, V.B.; Bondarenko, E.V.; Antoniuk-Shcheglova, I.A. Pineal gland melatonin-producing function in elderly patients with hypertensive disease: Age peculiarities. Adv. Gerontol. 2010, 23, 539-542. [CrossRef] [PubMed]

149. Goyal, A.; Terry, P.D.; Superak, H.M.; Nell-Dybdahl, C.L.; Chowdhury, R.; Phillips, L.S.; Kutner, M.H. Melatonin supplementation to treat the metabolic syndrome: A randomized controlled trial. Diabetol. Metab. Syndr. 2014, 6, 124. [CrossRef] [PubMed]

150. Peschke, E.; Bahr, I.; Muhlbauer, E. Experimental and clinical aspects of melatonin and clock genes in diabetes. J. Pineal Res. 2015, 59, 1-23. [CrossRef] 
151. Reutrakul, S.; Sumritsopak, R.; Saetung, S.; Chanprasertyothin, S.; Chailurkit, L.O.; Anothaisintawee, T. Lower nocturnal urinary 6-sulfatoxymelatonin is associated with more severe insulin resistance in patients with prediabetes. Neurobiol. Sleep Circadian Rhythm. 2018, 4, 10-16. [CrossRef]

152. Abood, S.; Abdulsahib, W.; Hussain, S.; Ismail, S. Melatonin potentiates the therapeutic effects of metformin in women with metabolic syndrome. Sci. Pharm. 2020, 88, 28. [CrossRef]

153. Cipolla-Neto, J.; Amaral, F.G.; Afeche, S.C.; Tan, D.X.; Reiter, R.J. Melatonin, energy metabolism, and obesity: A review. J. Pineal Res. 2014, 56, 371-381. [CrossRef] [PubMed]

154. Shenoy, S. Coronavirus (Covid-19) sepsis: Revisiting mitochondrial dysfunction in pathogenesis, aging, inflammation, and mortality. Inflamm. Res. 2020, 69, 1077-1085. [CrossRef] [PubMed]

155. Li, G.; Fan, Y.; Lai, Y.; Han, T.; Li, Z.; Zhou, P.; Pan, P.; Wang, W.; Hu, D.; Liu, X.; et al. Coronavirus infections and immune responses. J. Med. Virol. 2020, 92, 424-432. [CrossRef]

156. Pietrobon, A.J.; Teixeira, F.M.E.; Sato, M.N. Immunosenescence and inflammaging: Risk factors of severe COVID-19 in older people. Front. Immunol. 2020, 11, 579220. [CrossRef]

157. Mallapaty, S. The coronavirus is most deadly if you are older and male-New data reveal the risks. Nature 2020, 585, 16-17. [CrossRef] [PubMed]

158. Chen, L.D.; Zhang, Z.Y.; Wei, X.J.; Cai, Y.Q.; Yao, W.Z.; Wang, M.H.; Huang, Q.F.; Zhang, X.B. Association between cytokine profiles and lung injury in COVID-19 pneumonia. Respir. Res. 2020, 21, 201. [CrossRef]

159. Dorward, D.A.; Russell, C.D.; Um, I.H.; Elshani, M.; Armstrong, S.D.; Penrice-Randal, R.; Millar, T.; Lerpiniere, C.E.; Tagliavini, G.; Hartley, C.S.; et al. Tissue-specific tolerance in fatal Covid-19. medRxiv 2020. [CrossRef]

160. Xu, Z.S.; Shu, T.; Kang, L.; Wu, D.; Zhou, X.; Liao, B.W.; Sun, X.L.; Zhou, X.; Wang, Y.Y. Temporal profiling of plasma cytokines, chemokines and growth factors from mild, severe and fatal COVID-19 patients. Signal Transduct. Target. Ther. 2020, 5, 100. [CrossRef]

161. Blanco-Melo, D.; Nilsson-Payant, B.E.; Liu, W.C.; Uhl, S.; Hoagland, D.; Moller, R.; Jordan, T.X.; Oishi, K.; Panis, M.; Sachs, D.; et al. Imbalanced host response to SARS-CoV-2 drives development of COVID-19. Cell 2020, 181, 1036-1045. [CrossRef]

162. Yang, J.; Petitjean, S.J.L.; Koehler, M.; Zhang, Q.; Dumitru, A.C.; Chen, W.; Derclaye, S.; Vincent, S.P.; Soumillion, P.; Alsteens, D. Molecular interaction and inhibition of SARS-CoV-2 binding to the ACE2 receptor. Nat. Commun. 2020, 11, 4541. [CrossRef]

163. Ratajczak, M.Z.; Kucia, M. SARS-CoV-2 infection and overactivation of Nlrp3 inflammasome as a trigger of cytokine "storm" and risk factor for damage of hematopoietic stem cells. Leukemia 2020, 34, 1726-1729. [CrossRef]

164. Liu, Y.; Yang, Y.; Zhang, C.; Huang, F.; Wang, F.; Yuan, J.; Wang, Z.; Li, J.; Li, J.; Feng, C.; et al. Clinical and biochemical indexes from 2019-nCoV infected patients linked to viral loads and lung injury. Sci. China Life Sci. 2020, 63, 364-374. [CrossRef]

165. Reiter, R.; Sharma, R.; Ma, Q.; Liu, C.; Manucha, W.; González, P.; Dominguez-Rodriguez, A. Metabolic plasticity of activated immune cells: Advantages for suppression of COVID-19 Disease by melatonin. Melatonin Res. 2020, 3, 362-379. [CrossRef]

166. Hardeland, R.; Tan, D.-X. Protection by melatonin in respiratory diseases: Valuable information for the treatment of COVID-19. Melatonin Res. 2020, 3, 264-275. [CrossRef]

167. Hosseinzadeh, A.; Javad-Moosavi, S.A.; Reiter, R.J.; Hemati, K.; Ghaznavi, H.; Mehrzadi, S. Idiopathic pulmonary fibrosis (IPF) signaling pathways and protective roles of melatonin. Life Sci. 2018, 201, 17-29. [CrossRef] [PubMed]

168. Zhao, X.; Sun, J.; Su, W.; Shan, H.; Zhang, B.; Wang, Y.; Shabanova, A.; Shan, H.; Liang, H. Melatonin protects against lung fibrosis by regulating the Hippo/YAP pathway. Int. J. Mol. Sci. 2018, 19, 1118. [CrossRef] [PubMed]

169. Hardeland, R. Aging, melatonin, and the pro- and anti-inflammatory networks. Int. J. Mol. Sci. 2019, 20, 1223. [CrossRef] [PubMed]

170. Pal, P.K.; Chattopadhyay, A.; Bandyopadhyay, D. Melatonin as a potential therapeutic molecule against COVID-19 associated gastrointestinal complications: An unrevealed link. Melatonin Res. 2020, 3, 417-435. [CrossRef]

171. Zeppa, S.D.; Agostini, D.; Piccoli, G.; Stocchi, V.; Sestili, P. Gut microbiota status in COVID-19: An unrecognized player? Front. Cell. Infect. Microbiol. 2020, 10, 576551. [CrossRef]

172. Paulose, J.K.; Wright, J.M.; Patel, A.G.; Cassone, V.M. Human gut bacteria are sensitive to melatonin and express endogenous circadian rhythmicity. PLoS ONE 2016, 11, e0146643. [CrossRef]

173. Anderson, G.; Reiter, R. COVID-19 pathophysiology: Interactions of gut microbiome, melatonin, vitamin D, stress, kynurenine and the alpha 7 nicotinic receptor: Treatment implications. Melatonin Res. 2020, 3, 322-345. [CrossRef]

174. Zarezadeh, M.; Khorshidi, M.; Emami, M.; Janmohammadi, P.; Kord-Varkaneh, H.; Mousavi, S.M.; Mohammed, S.H.; Saedisomeolia, A.; Alizadeh, S. Melatonin supplementation and pro-inflammatory mediators: A systematic review and meta-analysis of clinical trials. Eur. J. Nutr. 2020, 59, 1803-1813. [CrossRef] [PubMed]

175. Tamtaji, O.R.; Mobini, M.; Reiter, R.J.; Azami, A.; Gholami, M.S.; Asemi, Z. Melatonin, a toll-like receptor inhibitor: Current status and future perspectives. J. Cell. Physiol. 2019, 234, 7788-7795. [CrossRef]

176. Farre-Alins, V.; Narros-Fernandez, P.; Palomino-Antolin, A.; Decouty-Perez, C.; Lopez-Rodriguez, A.B.; Parada, E.; MunozMontero, A.; Gomez-Rangel, V.; Lopez-Munoz, F.; Ramos, E.; et al. Melatonin reduces NLRP3 inflammasome activation by increasing alpha7 nAChR-mediated autophagic flux. Antioxidants 2020, 9, 1299. [CrossRef]

177. Choudhury, A.; Das, N.C.; Patra, R.; Mukherjee, S. In silico analyses on the comparative sensing of SARS-CoV-2 mRNA by the intracellular TLRs of humans. J. Med. Virol. 2021, 93, 2476-2486. [CrossRef] 
178. Volt, H.; Garcia, J.A.; Doerrier, C.; Diaz-Casado, M.E.; Guerra-Librero, A.; Lopez, L.C.; Escames, G.; Tresguerres, J.A.; AcunaCastroviejo, D. Same molecule but different expression: Aging and sepsis trigger NLRP3 inflammasome activation, a target of melatonin. J. Pineal Res. 2016, 60, 193-205. [CrossRef]

179. Zhang, Y.; Li, X.; Grailer, J.J.; Wang, N.; Wang, M.; Yao, J.; Zhong, R.; Gao, G.F.; Ward, P.A.; Tan, D.X.; et al. Melatonin alleviates acute lung injury through inhibiting the NLRP3 inflammasome. J. Pineal Res. 2016, 60, 405-414. [CrossRef] [PubMed]

180. De Rivero Vaccari, J.C.; Dietrich, W.D.; Keane, R.W.; de Rivero Vaccari, J.P. The inflammasome in times of COVID-19. Front. Immunol. 2020, 11, 583373. [CrossRef] [PubMed]

181. Cuadrado, A.; Pajares, M.; Benito, C.; Jimenez-Villegas, J.; Escoll, M.; Fernandez-Gines, R.; Garcia Yague, A.J.; Lastra, D.; Manda, G.; Rojo, A.I.; et al. Can activation of NRF2 be a strategy against COVID-19? Trends Pharmacol. Sci. 2020, 41, 598-610. [CrossRef] [PubMed]

182. Xia, Y.; Chen, S.; Zeng, S.; Zhao, Y.; Zhu, C.; Deng, B.; Zhu, G.; Yin, Y.; Wang, W.; Hardeland, R.; et al. Melatonin in macrophage biology: Current understanding and future perspectives. J. Pineal Res. 2019, 66, e12547. [CrossRef]

183. Carrillo-Vico, A.; Calvo, J.R.; Abreu, P.; Lardone, P.J.; Garcia-Maurino, S.; Reiter, R.J.; Guerrero, J.M. Evidence of melatonin synthesis by human lymphocytes and its physiological significance: Possible role as intracrine, autocrine, and/or paracrine substance. FASEB J. 2004, 18, 537-539. [CrossRef] [PubMed]

184. Fernandes, P.A.; Cecon, E.; Markus, R.P.; Ferreira, Z.S. Effect of TNF-alpha on the melatonin synthetic pathway in the rat pineal gland: Basis for a 'feedback' of the immune response on circadian timing. J. Pineal Res. 2006, 41, 344-350. [CrossRef] [PubMed]

185. Baumgartner, L.; Lam, K.; Lai, J.; Barnett, M.; Thompson, A.; Gross, K.; Morris, A. Effectiveness of melatonin for the prevention of intensive care unit delirium. Pharmacotherapy 2019, 39, 280-287. [CrossRef]

186. Bouhafs, R.K.; Jarstrand, C. Effects of antioxidants on surfactant peroxidation by stimulated human polymorphonuclear leukocytes. Free Radic. Res. 2002, 36, 727-734. [CrossRef]

187. Russell, O.M.; Gorman, G.S.; Lightowlers, R.N.; Turnbull, D.M. Mitochondrial diseases: Hope for the future. Cell 2020, 181, 168-188. [CrossRef]

188. Anand, S.K.; Tikoo, S.K. Viruses as modulators of mitochondrial functions. Adv. Virol. 2013, 2013, 738794. [CrossRef] [PubMed]

189. Tiku, V.; Tan, M.W.; Dikic, I. Mitochondrial functions in infection and immunity. Trends Cell Biol. 2020, 30, 263-275. [CrossRef] [PubMed]

190. Singh, K.K.; Chaubey, G.; Chen, J.Y.; Suravajhala, P. Decoding SARS-CoV-2 hijacking of host mitochondria in COVID-19 pathogenesis. Am. J. Physiol. Cell Physiol. 2020, 319, C258-C267. [CrossRef]

191. Thompson, E.A.; Cascino, K.; Ordonez, A.A.; Zhou, W.; Vaghasia, A.; Hamacher-Brady, A.; Brady, N.R.; Sun, I.H.; Wang, R.; Rosenberg, A.Z.; et al. Mitochondrial induced T cell apoptosis and aberrant myeloid metabolic programs define distinct immune cell subsets during acute and recovered SARS-CoV-2 infection. medRxiv 2020. [CrossRef]

192. Guzzi, P.H.; Mercatelli, D.; Ceraolo, C.; Giorgi, F.M. Master regulator analysis of the SARS-CoV-2/human interactome. J. Clin. Med. 2020, 9, 982. [CrossRef] [PubMed]

193. Srinivasan, S.; Cui, H.; Gao, Z.; Liu, M.; Lu, S.; Mkandawire, W.; Narykov, O.; Sun, M.; Korkin, D. Structural genomics of SARS-CoV-2 indicates evolutionary conserved functional regions of viral proteins. Viruses 2020, 12, 360. [CrossRef] [PubMed]

194. Wu, K.; Zou, J.; Chang, H.Y. RNA-GPS predicts SARS-CoV-2 RNA localization to host mitochondria and nucleolus. bioRxiv 2020. [CrossRef]

195. Gatti, P.; Ilamathi, H.S.; Todkar, K.; Germain, M. Mitochondria targeted viral replication and survival strategies-prospective on SARS-CoV-2. Front. Pharmacol. 2020, 11, 578599. [CrossRef]

196. Picca, A.; Lezza, A.M.S.; Leeuwenburgh, C.; Pesce, V.; Calvani, R.; Landi, F.; Bernabei, R.; Marzetti, E. Fueling inflamm-aging through mitochondrial dysfunction: Mechanisms and molecular targets. Int. J. Mol. Sci. 2017, 18, 933. [CrossRef] [PubMed]

197. Gardinassi, L.G.; Souza, C.O.S.; Sales-Campos, H.; Fonseca, S.G. Immune and metabolic signatures of COVID-19 revealed by transcriptomics data reuse. Front. Immunol. 2020, 11, 1636. [CrossRef]

198. Singh, K.; Chen, Y.C.; Judy, J.T.; Seifuddin, F.; Tunc, I.; Pirooznia, M. Network analysis and transcriptome profiling identify autophagic and mitochondrial dysfunctions in SARS-CoV-2 infection. bioRxiv 2020. [CrossRef]

199. Jin, J.M.; Bai, P.; He, W.; Wu, F.; Liu, X.F.; Han, D.M.; Liu, S.; Yang, J.K. Gender differences in patients with COVID-19: Focus on severity and mortality. Front. Public Health 2020, 8, 152. [CrossRef]

200. Ventura-Clapier, R.; Moulin, M.; Piquereau, J.; Lemaire, C.; Mericskay, M.; Veksler, V.; Garnier, A. Mitochondria: A central target for sex differences in pathologies. Clin. Sci. 2017, 131, 803-822. [CrossRef]

201. Kloc, M.; Ghobrial, R.M.; Kubiak, J.Z. The role of genetic sex and mitochondria in response to COVID-19 infection. Int. Arch. Allergy Immunol. 2020, 181, 629-634. [CrossRef]

202. Vazquez, C.; Horner, S.M. MAVS coordination of antiviral innate immunity. J. Virol. 2015, 89, 6974-6977. [CrossRef]

203. Jiang, H.W.; Zhang, H.N.; Meng, Q.F.; Xie, J.; Li, Y.; Chen, H.; Zheng, Y.X.; Wang, X.N.; Qi, H.; Zhang, J.; et al. SARS-CoV-2 Orf9b suppresses type I interferon responses by targeting TOM70. Cell. Mol. Immunol. 2020, 17, 998-1000. [CrossRef]

204. Miller, B.; Silverstein, A.; Flores, M.; Cao, K.; Kumagai, H.; Mehta, H.H.; Yen, K.; Kim, S.J.; Cohen, P. Host mitochondrial transcriptome response to SARS-CoV-2 in multiple cell models and clinical samples. Sci. Rep. 2021, 11, 3. [CrossRef]

205. Venegas, C.; Garcia, J.A.; Escames, G.; Ortiz, F.; Lopez, A.; Doerrier, C.; Garcia-Corzo, L.; Lopez, L.C.; Reiter, R.J.; AcuñaCastroviejo, D. Extrapineal melatonin: Analysis of its subcellular distribution and daily fluctuations. J. Pineal Res. 2012, 52, 217-227. [CrossRef] 
206. Suofu, Y.; Li, W.; Jean-Alphonse, F.G.; Jia, J.; Khattar, N.K.; Li, J.; Baranov, S.V.; Leronni, D.; Mihalik, A.C.; He, Y.; et al. Dual role of mitochondria in producing melatonin and driving GPCR signaling to block cytochrome c release. Proc. Natl. Acad. Sci. USA 2017, 114, E7997-E8006. [CrossRef] [PubMed]

207. Tan, D.-X.; Reiter, R. Mitochondria: The birth place, battle ground and the site of melatonin metabolism in cells. Melatonin Res. 2019, 2, 44-66. [CrossRef]

208. Huo, X.; Wang, C.; Yu, Z.; Peng, Y.; Wang, S.; Feng, S.; Zhang, S.; Tian, X.; Sun, C.; Liu, K.; et al. Human transporters, PEPT1/2, facilitate melatonin transportation into mitochondria of cancer cells: An implication of the therapeutic potential. J. Pineal Res. 2017, 62. [CrossRef]

209. Reiter, R.J.; Tan, D.X.; Rosales-Corral, S.; Galano, A.; Zhou, X.J.; Xu, B. Mitochondria: Central Organelles for Melatonin's Antioxidant and Anti-Aging Actions. Molecules 2018, 23, 509. [CrossRef] [PubMed]

210. Reiter, R.J.; Sharma, R.; Ma, Q.; Rorsales-Corral, S.; de Almeida Chuffa, L.G. Melatonin inhibits warburg-dependent cancer by redirecting glucose oxidation to the mitochondria: A mechanistic hypothesis. Cell. Mol. Life Sci. 2020, 77, 2527-2542. [CrossRef] [PubMed]

211. Tan, D.X.; Manchester, L.C.; Terron, M.P.; Flores, L.J.; Reiter, R.J. One molecule, many derivatives: A never-ending interaction of melatonin with reactive oxygen and nitrogen species? J. Pineal Res. 2007, 42, 28-42. [CrossRef]

212. Khomich, O.A.; Kochetkov, S.N.; Bartosch, B.; Ivanov, A.V. Redox biology of respiratory viral infections. Viruses 2018, 10, 392. [CrossRef]

213. Reiter, R.J.; Calvo, J.R.; Karbownik, M.; Qi, W.; Tan, D.X. Melatonin and its relation to the immune system and inflammation. Ann. N. Y. Acad. Sci. 2000, 917, 376-386. [CrossRef] [PubMed]

214. Ramis, M.R.; Esteban, S.; Miralles, A.; Tan, D.X.; Reiter, R.J. Protective effects of melatonin and mitochondria-targeted antioxidants against oxidative stress: A Review. Curr. Med. Chem. 2015, 22, 2690-2711. [CrossRef] [PubMed]

215. Gomez-Pastora, J.; Weigand, M.; Kim, J.; Wu, X.; Strayer, J.; Palmer, A.F.; Zborowski, M.; Yazer, M.; Chalmers, J.J. Hyperferritinemia in critically ill COVID-19 patients-Is ferritin the product of inflammation or a pathogenic mediator? Clin. Chim. Acta. 2020, 509, 249-251. [CrossRef] [PubMed]

216. Labonia, W.; Rubio, D.; Arias, C. Melatonin corrects reticuloendothelial blockade and iron status in haemodialysed patients. Nephrology 2005, 10, 583-587. [CrossRef] [PubMed]

217. Puelles, V.G.; Lutgehetmann, M.; Lindenmeyer, M.T.; Sperhake, J.P.; Wong, M.N.; Allweiss, L.; Chilla, S.; Heinemann, A.; Wanner, N.; Liu, S.; et al. Multiorgan and renal tropism of SARS-CoV-2. N. Engl. J. Med. 2020, 383, 590-592. [CrossRef] [PubMed]

218. Herrera, E.A.; Gonzalez-Candia, A. Comment on Melatonin as a potential adjuvant treatment for COVID-19. Life Sci. 2020, 253, 117739. [CrossRef] [PubMed]

219. Castillo, R.; Quizon, G.; Juco, M.; Roman, A.; De Leon, G.; Punzalan, F.; Guingon, R.B.; Morales, D.; Tan, D.-X.; Reiter, R. Melatonin as adjuvant treatment for coronavirus disease 2019 pneumonia patients requiring hospitalization (MAC-19 PRO): A case series. Melatonin Res. 2020, 3, 297-310. [CrossRef]

220. Gimenez, V.M.; Inserra, F.; Tajer, C.D.; Mariani, J.; Ferder, L.; Reiter, R.J.; Manucha, W. Lungs as target of COVID-19 infection: Protective common molecular mechanisms of vitamin D and melatonin as a new potential synergistic treatment. Life Sci. 2020, 254, 117808. [CrossRef]

221. DiNicolantonio, J.J.; McCarty, M.; Barroso-Aranda, J. Melatonin may decrease risk for and aid treatment of COVID-19 and other RNA viral infections. Open Heart 2021, 8, e001568. [CrossRef]

222. Chavarria, A.P.; Vazquez, R.R.V.; Cherit, J.G.D.; Bello, H.H.; Suastegui, H.C.; Moreno-Castaneda, L.; Alanis Estrada, G.; Hernandez, F.; Gonzalez-Marcos, O.; Saucedo-Orozco, H.; et al. Antioxidants and pentoxifylline as coadjuvant measures to standard therapy to improve prognosis of patients with pneumonia by COVID-19. Comput. Struct. Biotechnol. J. 2021, 19, 1379-1390. [CrossRef]

223. Ramos, A.; Miguez, M.P.; Morgado, S.; Sanchez-Correa, B.; Gordillo, J.J.; Casado, J.G.; Tarazona, R.; Regodon, S. Melatonin enhances responsiveness to dichelobacter nodosus vaccine in sheep and increases peripheral blood CD4 T lymphocytes and IgG-expressing B lymphocytes. Vet. Immunol. Immunopathol. 2018, 206, 1-8. [CrossRef]

224. Artigas, L.; Coma, M.; Matos-Filipe, P.; Aguirre-Plans, J.; Farres, J.; Valls, R.; Fernandez-Fuentes, N.; de la Haba-Rodriguez, J.; Olvera, A.; Barbera, J.; et al. In-silico drug repurposing study predicts the combination of pirfenidone and melatonin as a promising candidate therapy to reduce SARS-CoV-2 infection progression and respiratory distress caused by cytokine storm. PLoS ONE 2020, 15, e0240149. [CrossRef] [PubMed]

225. Seifirad, S.; Alquran, L. Commentary: Antifibrotics in COVID-19 Lung Disease: Let Us Stay Focused. Front. Med. (Lausanne) 2021, 7, 625440. [CrossRef] [PubMed]

226. Habtemariam, S.; Daglia, M.; Sureda, A.; Selamoglu, Z.; Gulhan, M.F.; Nabavi, S.M. Melatonin and respiratory diseases: A review. Curr. Top. Med. Chem. 2017, 17, 467-488. [CrossRef] [PubMed]

227. Silvestri, M.; Rossi, G.A. Melatonin: Its possible role in the management of viral infections-A brief review. Ital. J. Pediatr. 2013, 39, 61. [CrossRef] [PubMed]

228. Grilo-Bensusan, I.; Gomez-Delgado, E.; Gomez-Regife, L. Melatonin as a probable cause of diarrhoea. Rev. Esp. Enferm. Dig. 2015, 107, 119-120. [PubMed]

229. De Bleecker, J.L.; Lamont, B.H.; Verstraete, A.G.; Schelfhout, V.J. Melatonin and painful gynecomastia. Neurology 1999, 53, 435-436. [CrossRef]

230. Calvo, J.R.; Guerrero, J.M.; Osuna, C.; Molinero, P.; Carrillo-Vico, A. Melatonin triggers Crohn's disease symptoms. J. Pineal Res. 2002, 32, 277-278. [CrossRef] [PubMed] 